\title{
Trajetórias do planejamento urbano: o plano diretor da década de 1950 e o reordenamento urbano de Araraquara-SP
}

\author{
Rodrigo Alberto de Toledo \\ Doutor em Ciências Sociais (Universidade Estadual Paulista Júlio de Mesquita Filho) \\ Professor na Universidade Estadual Paulista Júlio de Mesquita Filho \\ São Paulo, São Paulo, Brasil \\ ro-toledo@hotmail.com.br
}

\begin{abstract}
Resumo Este artigo pretende dimensionar como a corrente urbanística forjada no Estado de São Paulo, especialmente a partir das teses de Anhaia Mello, catedrático da Faculdade de Arquitetura e Urbanismo da Universidade de São Paulo (FAU-USP), se cristalizou no primeiro plano diretor elaborado na cidade de Araraquara a partir de 1950. Procuramos estruturar como ocorreu esse processo de cristalização da corrente urbanística paulista, de matizes francesa e anglo-americana, na cidade de Araraquara, ou seja, quais foram os interlocutores fundamentais, além do próprio Anhaia Mello, para que essa transferência de conhecimento sobre planejamento urbano se efetivasse no município. Identificamos em levantamento das fontes primárias da pesquisa de doutorado Trajetórias do planejamento urbano em Araraquara: do centralismo decisório ao plano diretor participativo, no Arquivo Histórico Intermediário de Araraquara, na Biblioteca da FAU-USP, nos acervos de Anhaia Mello e do Centro de Pesquisa e Estudos Urbanísticos (CEPEU), que as propostas urbanistas gestadas na FAU-USP foram difundidas e incorporadas nas normas urbanísticas de Araraquara ditando os rumos do processo de formulação de políticas públicas urbanas no município a partir de meados da década de 1960.
\end{abstract}

Palavras-chave: planejamento urbano, plano diretor, desenvolvimento urbano, políticas públicas e democracia.

\section{Introdução}

耳 ste artigo é produto da sistematização e análise dos dados coleta- dos no Centro de Documentação em Arquitetura e Urbanismo da USP, nos registros da história departamental e de atividades didático-pedagógicas pregressas dos professores que atuaram na Faculdade de Arquitetura e Urbanismo da USP, no acervo da Biblioteca da USP da Rua Maranhão, no Arquivo Histórico Intermediário de Araraquara e nas leituras da bibliografia.

Dividimos esse artigo em três seções. Na primeira - "Boaventura Gravina: um interlocutor das correntes urbanistas paulistas na cidade de Araraquara" -, há um conjunto de informações da década de 1950, em que Araraquara focalizou a necessidade de elaboração de um plano diretor no processo de transformações econômicas pelas quais ela estava passando como, por exemplo, os impactos gerados na implantação 
de um parque industrial para a produção de suco de laranja. Naquele momento, o investidor imobiliário local Boaventura Gravina atuou tenazmente na tentativa de criar em Araraquara um ambiente propício para o estabelecimento de normas urbanísticas formuladas por Anhaia Mello, catedrático da FAU-USP.

A ampla quantidade de documentos, leis, portarias e artigos de jornais conduziram-nos na análise sobre a construção e finalização do primeiro plano diretor dessa cidade que se inicia em 1951 e é efetivamente implantado em 1977, tema da segunda seção - "O início dos debates sobre a necessidade de um plano diretor para Araraquara”. São desse período os primeiros esforços de se produzir um levantamento aerofotogramétrico que pudesse fornecer subsídios para os estudos sobre o Plano Diretor e direcionar intervenções necessárias na rede de água e esgotos com a finalidade de suas ampliações. Um achado importante da pesquisa foi um conjunto de fotos aéreas de Araraquara, produzidas entre 1952 e 1956 pelo Aero Club [sic.] de Araraquara, que desvendou uma cidade que já trazia em seu traçado, mesmo sem ainda possuir um plano diretor, a marca do planejamento ou da setorização.

A terceira seção - "A estruturação da comissão do plano diretor e o papel do Rotary Club e da Associação de Arquitetos e Engenheiros de Araraquara" - analisa o processo de formulação do plano como fruto da urbanização e da diversificação econômica pelo qual passava a cidade.

Além desse aspecto, na década de 1950, se por um lado Araraquara vivia um momento caracteristicamente centralizador no processo decisório, por outro, foi identificada, a priori, uma abertura política com a participação do Rotary, da Associação de Engenharia e do Centro de Pesquisas e Estudos Urbanísticos da USP na elaboração do Plano Diretor da cidade, o que nos revelou uma patente discrepância entre o centralismo político característico do processo decisório local e a metodologia aplicada para a elaboração do plano diretor da cidade. No entanto, a análise documental minuciosa efetuada no Arquivo Histórico Intermediário Municipal de Araraquara, as entrevistas realizadas com os atores remanescentes daquele processo e a caracterização dos membros pertencentes a essas associações revelaram que se tratava de atores sociais e economicamente incluídos na elite cultural e econômica do município. Assim, a participação das associações civis não refletia abertura política, mas sim compromisso político com a elite local pertencente a essas associações. Em outras palavras, representou um rearranjo na forma de conduzir as demandas locais, o clientelismo de massas (Kerbauy, 2000).
Essa seção ainda evidencia que o processo de elaboração do Plano Diretor de Araraquara foi marcado, na maior parte do período em questão (1955-1969), pelo forte cunho tecnocrático em suas práticas, a presença marcante dos interesses imobiliários vinculados à acumulação urbana e a ausência de possibilidades de participação cidadã na cunhagem das políticas produzidas e ofertadas.

\section{Boaventura Gravina, um interlocutor das correntes urbanistas paulistas na cidade de Araraquara}

\begin{abstract}
O Gravina participava de todos os fóruns de debates e Associações de Araraquara, uma pessoa culta, um investidor, uma pessoa rica. Ele planava sobre todas as Associações. Diziam que ele morava aqui e era dono do mundo.
\end{abstract}

Alcyr Azzoni ${ }^{1}$

Anhaia Mello, catedrático da FAU-USP e fundador do CEPEU teve amplo trânsito pela cidade de Araraquara - difundindo em todos os momentos as noções fundamentais para a elaboração de Planos Diretores -, cristalizando a corrente urbanista forjada no Estado de São Paulo no primeiro Plano Diretor da cidade, concluído na década de 1970. Neste artigo, procuramos estruturar como ocorreu esse processo de cristalização da corrente urbanista paulista, de matizes francesa e anglo-americana, na cidade de Araraquara, ou seja, quais foram os interlocutores fundamentais, além do próprio Anhaia Mello e de Boaventura Gravina, para que essa transferência de conhecimento sobre o planejamento urbano se efetivasse na cidade.

A figura de Boaventura Gravina no processo de consolidação de um Plano Urbanístico para Araraquara foi muito importante. Num primeiro momento, de um entusiasta das propostas urbanísticas gestadas na FAU-USP, transformou-se em um ferraz articulador na transposição das propostas urbanísticas geradas em São Paulo, especificamente àquelas do CEPEU, para Araraquara. Entretanto, assim como Ramos de Azevedo e Anhaia Mello, em São Paulo, Gravina, em Araraquara, foi um grande empreendedor imobiliário. Proprietário de várias residências, de imensas áreas que margeavam o município e loteador, "fundou", durante o final da década de 1970 e toda década de 1980, vários bairros (Vila Normanda e Jardim Higienópolis, Vila Guanabara) ditando os rumos 
do desenvolvimento de parte da malha urbana do município. Ao mesmo tempo em que colaborou com a formulação de normas urbanísticas locais, atuou como empreendedor imobiliário obtendo significativa renda imobiliária com a construção de residências, prédios e loteamentos.

Em entrevista à senhora Vanda Gravina, viúva de Boaventura, ela afirmou que o espírito empreendedor do esposo foi herdado do seu pai Vincenzo Gravina. No início do século, Vincenzo emigrou para o Brasil, deixando a esposa e um filho, para fazer riqueza aqui. Estabeleceu-se em Araraquara e abriu uma loja de Secos \& Molhados na esquina da Rua 9 de Julho com a Duque de Caxias. Após alcançar estabilidade financeira, retornou para a Itália para buscar a esposa e o filho Biaggio Gravina, que, posteriormente, formou-se em medicina na Itália, com especialidade em otorrinolaringologia e fora muito conhecido dentre a comunidade italiana de São Paulo. Vincenzo teve mais três filhos, todos se formaram em Engenharia na Itália: Pedro Gravina, Osvaldo Gravina e Boaventura Gravina.

Dos três irmãos, Pedro Gravina alçou carreira internacional e atuou por longo período como professor; primeiro, na Faculdade de Engenharia de Milão por cerca de quatro anos e, depois, na Universidade de Roma onde, provavelmente, aposentou-se. Quando retornou ao Brasil, desempenhou diversas atividades junto com urbanistas paulistanos, inclusive Anhaia Mello que, certamente, já havia entrado em contato com ele na Itália, na Universidade de Roma, pois era frequentador assíduo de congressos no exterior, especialmente na Europa e nos Estados Unidos.

Alcyr Azzoni afirma que,

em Araraquara, ele (Boaventura Gravina) era extremamente discreto. Ele tinha milhões de coisas em Bragança Paulista, Norte do Paraná, São José do Rio Preto. Aqui em Araraquara, ele teve [sic.] certamente uma presença muito forte em cima [sic.] de outros investidores acredito assim, dentro desse sistema do Rotary faziam assim: Ahh! [sic.] O Gravina comprou, então é bom [sic.]. Ele tinha o tino para investimentos. Não vejo que ele tenha se privilegiado de informações para esses investimentos, posso estar equivocado. Mas ele já tinha um conhecimento muito grande disso tudo, ele já participava de diversos locais em que se discutia isso. Em 1966, quando mudei-me para Araraquara, Gravina já era reconhecido como um investidor, um empresário metido em mil coisas. (Azzoni, entrevista concedida ao autor em outubro de 2011)

Também em entrevista, Vanda Gravina relata que, quando se casou com Boaventura Gravina, ele trabalhava com o Manoel Rodrigues, eles construíam estradas de rodagem. Ele era o Engenheiro de Manoel Rodrigues. Depois de quatro anos com Manoel Rodrigues, nos casamos. Ele havia acabado de chegar da Itália. Então ele começou a trabalhar por conta própria e ele fazia parte do Rotary. Foi presidente do Club, foi governador. Representou por diversas vezes o presidente do Rotary Nacional em países da Europa: Itália, Portugal, Suíça, França e na Espanha. Ele esteve na Itália por três vezes representando o presidente do Rotary. Ele também foi representante do consulado da Itália em Araraquara. (Vanda Gravina, entrevista concedida ao autor em outubro de 2011)

Certamente, o trabalho desenvolvido com $\mathrm{Ma}-$ noel Rodrigues e a atuação no Rotary Club fizeram de Gravina uma pessoa conhecida e, desde o início de suas atividades, detentor de informações privilegiadas que orientaram os seus investimentos.

A entrevista com a Sra. Vanda Gravina revelou que a atuação no Rotary Club possibilitava a Boaventura Gravina duas coisas: primeiro, um contato com elites econômicas nas cidades que visitava para fundar Associações Rotarianas; segundo, a partir desses contatos, provavelmente, Gravina colhia informações acerca das potencialidades imobiliárias da cidade ou região e não titubeava em adquirir terras, por mais distantes que fossem de Araraquara, sua cidade natal.

Segundo a Sra. Vanda Gravina, Boaventura

começou sua atuação profissional em Araraquara e depois iniciou construções em São Paulo. Formou uma fazenda no Paraná e duas no Mato Grosso. Ele tinha negócios em diversas regiões e ao mesmo tempo era Rotariano, era engenheiro. Ele tinha várias atividades ao mesmo tempo. Em Araraquara ele tinha terrenos, construções. Ele trabalhava muito "espalhado" [sic.] em diversas atividades. Ele ia para o Mato Grosso, para o Paraná, ele tinha uma vida muito ativa, porém fora de Araraquara também. (Vanda Gravina, entrevista concedida ao autor em outubro de 2011)

No Arquivo Histórico de Araraquara (o também denominado Arquivo Intermediário), no Processo n. 482-58 - Espólio de Boaventura Gravina -, identificamos que o ano de 1958 é o marco inicial das suas atividades especulativas imobiliárias. O contato privilegiado com o meio político local, a participação em Clubs de serviços e o seu envolvimento em comissões urbanísticas fizeram com que direcionasse os seus investimentos para a aquisição de terras nas regiões de expansão da malha urbana do município. Esse procedimento colocou nas mãos de Gravina, estrategicamente, áreas que, a partir da década de 1980, eram importantes para os projetos políticos de insta- 
lação de equipamentos urbanos, órgãos do governo federal e estadual assim como empresas. Gravina se utilizou muito desse expediente para construir uma proximidade com o poder público local. Proximidade esta que era utilizada, inclusive, para solicitar do poder público o perdão da cobrança de IPTU'S atrasados. $^{2}$

Além disso, Azzoni (2011) nos chama a atenção para o fato de Boaventura Gravina

e o Dinucci ${ }^{3}$ serem meio como se fossem os orientadores dos investimentos imobiliários, ou seja, o seu investimento em determinadas áreas acabava incentivando com que outros também investissem.

A propriedade de diversas áreas em Araraquara também colocava Gravina como um interlocutor indispensável na instalação de equipamentos e órgãos do governo estadual e federal. Por meio de doações de áreas, Gravina sedimentava a sua relação com o poder político e, ao mesmo tempo, promovia ganhos imobiliários com a valorização da terra, que permanecia de sua propriedade, nas proximidades da instalação do equipamento urbano ou órgão estadual ou federal. ${ }^{4}$

\section{O início dos debates sobre a necessidade de um Plano Diretor para Araraquara}

Em 1951, por meio do Ofício n. 209/51, de 26 de maio, a Câmara Municipal de Araraquara envia ao Executivo o autógrafo da lei aprovada, que, em seu artigo $1^{\circ}$, determinava a contratação de técnico de reconhecida competência para elaborar o Plano Urbanístico da cidade. $\mathrm{O}$ artigo $2^{\circ}$ orientava que o pagamento desse trabalho, "embora encetado e concluído no mesmo período", ano de 1951, seria efetuado no exercício de 1952, com verba consignada no respectivo orçamento. No $3^{\circ}$ artigo, a lei destinava uma verba máxima para a execução dos serviços de CR \$ 100.000,00 (cem mil cruzeiros). Esta lei, por sua vez, foi vetada posteriormente pelo prefeito engenheiro José dos Santos, em virtude do parecer da Diretoria de Expediente afirmando que a referida lei ofendia o artigo 33 da Lei Orgânica do Município que dizia que a "iniciativa dos projetos de lei cabe a qualquer vereador e ao prefeito, sendo privativa deste a do projeto de lei orçamentária”. O autógrafo de lei encaminhado pela câmara para a criação do Plano Urbanístico, em seu artigo $2^{\circ}$, determinava que o pagamento do trabalho, embora encetado e mesmo concluído no presente exercício, seria efetuado no exercício de 1952, com verba consignada no referido orçamento. Segundo a Diretoria de Expediente, a iniciativa de lei orçamentária, nos termos da Lei Orgânica do Município, cabia ao prefeito e não à câmara. Portanto, procedendo como determinava a lei elaborada pela câmara, que autorizava o início dos trabalhos para o desenvolvimento do Plano Urbanístico já projetando reserva orçamentária para sua consecução, ocorreria invasão da esfera de competência do Executivo. Além desse fator, o parecer elaborado pela Diretoria de Expediente também fazia referência ao fato de a Lei Orgânica do Município, em seu artigo $81^{\circ}$, determinar que "toda lei que crie ou aumente despesa, constará a indicação de recursos hábeis para prover os novos encargos". Assim, se a Câmara $\mathrm{Mu}-$ nicipal estivesse prevendo verba futura, desobedeceria às normas financeiras. Seguindo essas orientações, em $1^{\circ}$ de junho de 1951, o prefeito Antonio Tavares Pereira Lima vetou no todo o projeto de lei que autorizava o início dos trabalhos para a elaboração do Plano Urbanístico de Araraquara.

Em 1953, o presidente da Câmara Municipal, Mário Ananias, envia novamente para o Executivo, por meio do Ofício n. 2173/53, de 7 de agosto, o autógrafo de Lei n. 62/53, que autorizava o prefeito a contratar um técnico de reconhecida competência para elaborar o Plano Urbanístico da cidade. O autógrafo dessa lei não se diferenciou do já produzido em 1951. O polêmico artigo $2^{\circ}$ que, em grande parte, ocasionou o veto do prefeito Antonio Tavares Pereira Lima naquele ano, apresenta a seguinte redação:

Artigo $2^{\circ}$ - O pagamento desse trabalho, embóra [sic.] encetado e mesmo concluido [sic.] no presente exercício, será efetuado no exercício de 1954, com verba própria consignada no respectivo orçamento.

$\mathrm{O}$ artigo $3^{\circ}$, que tratava das despesas para a execução do Plano Urbanístico, também sofreu alterações em comparação ao autógrafo de lei vetado em 1951:

2. Encontramos diversas cobranças da Seção de Cadastro da Prefeitura Municipal de Araraquara no Espólio de Boaventura Gravina (Processo $n$. 482-58), tais como as emitidas em 6/7/1984; 3/9/1984; e 9/9/1984.

3. Registrado no CREA desde 1935, Camillo Dinucci era engenheiro civil e responsável pela Construtora Comercial Torello Dinucci, que ganhou as concorrências da Diretoria de Obras Públicas (DOP) para a construção de grupos escolares nas cidades de Colina, São Miguel Arcanjo e Glicério, da Cadeia de Penápolis e do Fórum de Araraquara (Ficher, 2005).

4. Doação de área de 2.016,00 $\mathrm{m}^{2}$ para a construção da Telesp; doação de área de 3.300,00 $\mathrm{m}^{2}$ para a construção do Centro de Triagem Regional dos Correios; doação de área de $1.025,00 \mathrm{~m}^{2}$ para a construção da Avenida Marginal de Araraquara, conhecida atualmente como Via Expressa (Processo n. 482-58, Espólio de Boaventura Gravina, do Arquivo Histórico Intermediário de Araraquara-SP). 
Artigo $3^{\circ}$ - A despêsa [sic.] com a execução da presente lei não poderá ultrapassar de $\operatorname{Cr} \$ 500.000,00$ (quinhentos mil cruzeiros).

Em 11 de agosto, a lei é promulgada pelo prefeito sob o número 298 e, no dia 27 daquele mês, publicada no jornal O Imparcial. Em 24 de maio de 1954, o presidente da Câmara Municipal José Amaral Vellosa encaminha, para o prefeito Antonio Tavares Pereira Lima, o Ofício n. 1241/54 relatando a aprovação em seção extraordinária do autógrafo número 16/54, que alterava o dispositivo da Lei n. 298, de 11 de agosto de 1953. Esse novo autógrafo alterava a data de execução do Plano Urbanístico para o exercício de 1955. Em $1^{\circ}$ de junho de 1954, o Executivo aprova o autógrafo encaminhado pela câmara, sob a Lei n. 341, alterando o dispositivo da Lei n. 298 de 11 de agosto de 1953. Em 2 de junho de 1954, o jornal O Imparcial publica a Lei n. 341 que alterava o dispositivo da Lei n. 298, de 11 de agosto de 1953. Ao que tudo indica, tendo em vista os documentos analisados no Arquivo Histórico do Município de Araraquara, a cidade estava caminhando para, efetivamente, consolidar seu primeiro Planejamento Urbanístico. No entanto, para que isso fosse possível o município tinha, necessariamente, de investir em recursos humanos e materiais para a elaboração de um detalhado memorial da cidade de Araraquara.

Data de 17 de outubro de 1952 a primeira solicitação da Diretoria de Obras e Serviços Públicos de Araraquara (DOSP) feita pelo engenheiro Neander de Campos Kerr, diretor da DOSP, ao prefeito Pereira Lima, para a realização de levantamento aerofotogramétrico. Em 29 de outubro de 1952, um ofício assinado pelos senhores Esmael Malavolta, encarregado da secretaria, e por Tancredo Monteiro do Amaral Castro, presidente do Aero Club [sic.] de Araraquara, com sede no edifício da Prefeitura Municipal de Araraquara, informava à prefeitura que o Club teria condições de efetuar serviço de levantamento aerofotogramétrico em planimetria à altura de 900 e 1000 metros. Não consta nos processos analisados no Arquivo Histórico do Município de Araraquara, edital de convocação de concorrência pública para a realização dos referidos serviços. Mas, uma análise do material produzido por esse levantamento deixa claro que ficou aquém das necessidades do município, ou seja, o Aero Club não dispunha de instrumentos nem de conhecimentos técnicos suficientes para fazer um levantamento aerofotogramétrico preciso. Este levantamento era fundamental para subsidiar o poder público local de informações necessárias para a elaboração do primeiro conjunto de fotografias aéreas capazes de uma restituição fotogramétrica da área da cidade de Araraquara, com curvas de nível e identificação das vias públicas com respectivos meios-fios ou passeios, refúgios ou abrigos, árvores situadas nos logradouros públicos etc.

Em que pese o grande valor histórico das imagens produzidas pelo Aero Club de Araraquara em 1952, a finalidade a que elas deveriam atender acabou sendo frustrada, ou seja, para que pudessem ser utilizadas como base de dados para a elaboração de plantas altimétricas, com as devidas curvas de níveis, deveriam ter sido produzidas em maior escala, 1:5000 ou 1:2000, e não 1:900. Além disso, a cidade não teve toda a sua área coberta e algumas imagens ficaram ofuscadas por terem sido produzidas sem a utilização de instrumentos próprios para a estabilização do equipamento fotográfico em pleno voo.

Paralelamente ao processo de produção de um levantamento aerofotogramétrico de Araraquara, o município também caminhava com a tarefa de montagem das Comissões do Plano Diretor.

A Portaria n. 870, de 28 de fevereiro de 1955, assinada pelo prefeito Rômulo Lupo, destacava a importância de elaboração de um Plano Diretor para a cidade. Nela havia referência ao processo iniciado em 1952 que, segundo consta, não se realizou por motivos de ordem financeira. Os estudos relativos à elaboração do plano recebiam a colaboração do professor Anhaia Mello, então diretor da FAU-USP.

Ao mesmo tempo em que se configurava a formação da equipe que elaboraria o primeiro Plano Diretor de Araraquara, o prefeito Lupo também investia na criação de um levantamento aerofotogramétrico mais preciso da cidade. ${ }^{5}$

Em 19 de agosto de 1956, no jornal O Imparcial, foi publicado o edital n. 173, assinado pelo prefeito Rômulo Lupo, abrindo por 10 dias, a contar da primeira publicação, concorrência pública para o levantamento aerofotogramétrico de Araraquara. Esse edital foi publicado ainda nas datas de 26 e 29 de agosto de 1956. Nesse segundo momento, notamos que a prefeitura foi mais criteriosa ao definir o tipo de serviço a ser realizado. Constam detalhes em edital, tais como a área de cobertura do levantamento, $30 \mathrm{~km}^{2}$, e uma exigência de que a execução deveria seguir todas as orientações e especificações técnicas estabelecidas pela Diretoria de Obras Sanitárias da Secretaria de Viação de Obras Sanitárias do Estado de São Paulo. Essas exigências eram fundamentais, uma vez que o levantamento fundamentaria a elaboração do projeto de água e esgoto, galerias pluviais e cadastro da cidade de Araraquara para a obtenção, por parte do Município, de um empréstimo do governo do estado, destinado à remodelação, ampliação da atual rede de água e esgoto. As propostas dos interessados em executar o 
trabalho de levantamento deveriam conter o preço do serviço e as condições de pagamento, o prazo do término do serviço, o atestado de referência de execução de serviço de idêntica natureza e a prova da idoneidade financeira e profissional. Chamou-nos a atenção o item III do referido edital, pois a prefeitura do município reservava-se ao direito de julgar livremente a concorrência, optando pela que, a seu juízo, oferecesse melhores condições ou pela recusa de todas se nenhuma delas conviesse aos interesses do município.

Após a análise das propostas e já com a decisão de qual empresa realizaria o serviço, a prefeitura de Araraquara envia uma série de ofícios a órgãos estaduais e prefeituras solicitando informações sobre a empresa Aeromapa Brasil Ltda. A Divisão de Águas do Ministério da Agricultura, em São Paulo, foi o primeiro órgão da administração federal a receber o Ofício n. 647/56, de 18 de agosto, da prefeitura de Araraquara, solicitando informações quanto à idoneidade da referida empresa. Em resposta, Raymundo Francisco Ribeiro Filho, chefe do $1^{\circ}$ Distrito da Divisão de Águas do Departamento Nacional de Produção Mineral (DNPM), informa que a Aeromapa Brasil Ltda. havia feito diversos levantamentos aerofotogramétricos, sendo os seus trabalhos honestos e idôneos. Diversos outros ofícios foram encaminhados à prefeitura de Santo André, Caçapava e Campinas e todas confirmaram que a empresa Aeromapa havia preenchido plenamente os requisitos técnicos desejados.

No dia 20 de setembro de 1956, foi assinado o termo de contrato entre a prefeitura municipal de Araraquara e a empresa Aeromapa Brasil Ltda. para a execução de levantamento aerofotogramétrico de uma área mínima de $30 \mathrm{Km}^{2}$ na escala 1:2.000, compreendendo toda a área edificada e arruada da cidade. Segundo a cláusula $8^{a}$ do contrato assinado, a empresa Aeromapa teria o prazo de oito meses para a conclusão dos levantamentos. O Departamento do Serviço Geográfico do Ministério da Guerra emitiu autorização para a realização dos trabalhos no dia $1^{\circ}$ de novembro de 1956.

Em ofício datado de 4 de dezembro de 1957, encaminhado à prefeitura de Araraquara, a empresa Aeromapa informa que os serviços de levantamento aerofotogramétrico haviam sido finalizados, perfazendo uma área de $39 \mathrm{Km}^{2}$ cobertos em escala de 1:2.000.

Concomitante ao processo de elaboração do estudo aerofotogramétrico da cidade, a prefeitura estabelece contatos com a Empresa de Construções e Saneamento Ltda. (ECOSA), em 7 de julho de 1956, para a elaboração de proposta de execução de levantamento aerofotogramétrico cadastral da cidade, estudos e projetos de ampliação do sistema de abastecimento de água e do sistema de esgoto, estudos e projetos de galeria de águas pluviais. Segundo informações que constam no referido documento, "estes estudos destinam-se à construção da ampliação dos serviços existentes, atualmente, em estado deficiente".

Como podemos perceber, a década de 1950 foi importante para a sedimentação de um conjunto de estudos cristalizados numa proposta de cidade que, segundo o imaginário da época, deveria se realizar por meio de um Plano Urbanístico. Na próxima seção, faremos uma análise documental desse intrincado processo de elaboração do Plano Urbanístico de Araraquara que, aos poucos, passou a ser denominado Plano Diretor.

\section{A estruturação da comissão do Plano Diretor em 1950 e o papel do Rotary Club e da Associação de Arquitetos e Engenheiros de Araraquara}

A década de 1950 foi importante para o município de Araraquara no que diz respeito ao planejamento urbano. Identificamos nesse período um conjunto de forças econômicas, políticas e sociais cristalizadas no Rotary Club local e na Associação de Engenharia, com atuação efetiva na elaboração do Plano Diretor da cidade. Tal fato configurou-se em virtude da crescente urbanização dos municípios do interior; da integração do sistema de comunicação que rompe seu isolacionismo; da presença mais efetiva da aparelhagem governamental, que marca a preponderância do poder público, especialmente no controle da violência e das fraudes eleitorais, e que acaba, assim, com a autonomia dos núcleos privados; da participação também mais efetiva do eleitorado; do estabelecimento de novos tipos de relações políticas, fatores esses que promoveram a ruptura com o modelo anterior de barganha das benesses públicas, reconfigurando o que Kerbauy (2000) denominou clientelismo de massas.

A ferrovia, principal sistema de transporte e comunicação - símbolo do progresso tecnológico do final do século XIX no interior paulista -, trouxe uma série de vantagens para a região. Ela permitiu, por exemplo, a ampliação do comércio, a instalação do telégrafo e dos serviços diários dos correios, o que diminuiu a distância do principal centro urbano, a cidade de São Paulo. Além dessas mudanças, a abolição da escravidão no Brasil conduziu, ao longo da segunda metade do século XIX, à inserção de trabalhadores livres nas lavouras de café. Dessa forma, a facilidade de transporte e de comunicação, propiciada pela ferrovia, torna-se o impulso das profundas transformações pelas quais o mundo rural estava passando. 
Essas transformações ocorreram na medida em que a economia cafeeira gerou condições para o arranque industrial, ao contrário das primeiras fazendas, que seguiam o molde dos engenhos como unidades quase autossuficientes e que estabeleciam, muito timidamente, relações com o meio urbano. Isso ocorreu porque seus proprietários começaram a vê-las como fontes geradoras de renda, cujos lucros eram aplicados na criação e ampliação de outros negócios, como bancos, casas comissárias, imóveis urbanos e companhias de prestação de serviços (Benincasa, 2003). Essa reorganização econômica do interior transformou as relações sociais e, consequentemente, a ocupação do espaço urbano e rural da região. A facilidade de transporte de materiais através da ferrovia trouxe inovações, do ponto de vista arquitetônico, para as sedes das fazendas e para as cidades. A ferrovia estabeleceu um relacionamento comercial mais estreito e constante também com os grandes centros de produção industrial, como a Inglaterra, onde, na segunda metade do século XIX, estava em pleno curso a segunda fase de sua industrialização. Essa fase é marcada pelo aumento da produção industrial, alicerçada nas indústrias de bens de capital, no carvão, no ferro e no aço (Hobsbawm, 1979). Em nenhuma outra época, a taxa de crescimento das exportações britânicas havia crescido tanto como entre 1840 e 1860 , o que beneficiou, sobretudo, os novos bens de capital, que, em 1840-1842, compreendiam cerca de $11 \%$ do valor das exportações britânicas de manufaturados; em 1857-1859, essa proporção subiu para 22\% e, em 1882-1884, para 27\%. Hobsbawm (1979) afirma que a revolução operada nos transportes pela estrada de ferro e pela navegação a vapor, importantes meios de exportações britânicas de ferro, aço e carvão, deu ainda impulso à abertura de novos mercados e à expansão dos antigos.

Todas essas transformações tiveram impactos significativos na região de Araraquara, os quais a conduziram para uma constante reflexão sobre a forma de ocupação e uso de seu solo. É inegável que, a despeito do enorme impulso que a economia local teve com a cultura do café - além da introdução de novas técnicas arquitetônicas e de ações sobre o espaço da cidade, que indicam a gênese de um processo de planejamento urbano -, a cidade entrou em contato com uma onda epidêmica de febre amarela que varria o estado de São Paulo. O café, cultura que necessitava de modernização do transporte e que propiciou a introdução da estrada de ferro, continuou sendo a maior fonte geradora de riquezas de Araraquara até a década de 1930; o ciclo foi rompido em virtude da crise de 1929, com a quebra da bolsa de valores de Nova Iorque.

O processo de urbanização e de rompimento com o isolacionismo interiorano evidentemente teve um custo. Para as cidades do interior paulista, o contato com populações vindas de outras regiões, somado à precariedade de equipamentos públicos e das unidades habitacionais, criaram condições favoráveis para o surgimento de pandemias. O governo do estado, em franco processo de estímulo à imigração, não pôde se manter impassível diante desse quadro. Assim, criou a Comissão Sanitária, que tinha como tarefa produzir estudos urbanísticos e fazer intervenções profiláticas para reverter o quadro grave de epidemias em diversas cidades do interior paulista, inclusive em Araraquara. Theodoro Sampaio, em 1892, escreveu um ofício ao secretário de negócios do interior, Cesário Motta Júnior, propondo a criação de um serviço sanitário e de uma infraestrutura urbano-sanitária na cidade. Num segundo ofício, Sampaio delimitava a área principal de criação da infraestrutura: o bairro de Santa Efigênia, que reunia as condições topográficas, de drenagens e sofria com a aglomeração de seus habitantes, amontoados em construções, por vezes, desfavoráveis e desprovidas de higiene. Três meses depois, a suspeita de Sampaio se confirmava na forma de uma epidemia de febre amarela com foco no bairro de Santa Efigênia. O serviço sanitário tinha como uma de suas premissas, evocada pelas autoridades sanitárias e governamentais, o controle da vida urbana, fato evidente desde seu primeiro esboço de legislação sanitária (1892) até a formalização do Código Sanitário de 1918, pois, segundo Telarolli Júnior (1993, p. 139),

enfatizava o controle das doenças transmissíveis através da ação sobre o espaço urbano, com a larga utilização da engenharia sanitária, e de ações de política médica em campanhas contra as epidemias, nos primeiros quinze anos, e mais tarde, as endemias.

Nesse mesmo ano de 1892, foi nomeada a Comissão de Exame e Inspeção das Habitações Operárias e Cortiços no distrito de Santa Efigênia, que elaborou um relatório, resultando em 1894 no Código Sanitário Estadual. Segundo Campos (2002), esse código, que dava suporte às ações profiláticas por todo o Estado, vigorou por pouco tempo, sendo substituído em 1896 por outra legislação sanitária. As alterações, no entanto, não produziram uma total reformulação do código e sua essência continuou sendo o teor do código de 1894.

Os códigos sanitários produzidos a partir do final do século passado definiram os modelos de urbanização e edificação que ainda hoje se refletem nas exigências da legislação. Estes códigos surgem como resultado de uma intensa ação institucional de enfrentamento dos problemas epidêmicos. O Código Sanitário de 1894 (Decreto n. 233) contém orientações relativas à captação de água para abastecimento, 
disposição de esgotos e de lixo, ocupação de terrenos úmidos e pantanosos e sobre as condições de funcionamento de prédios de acesso público diverso. Contém também todo um conjunto de exigências relativas às vias de circulação e às edificações residenciais, que interferem no padrão de ocupação urbana verificada ainda nos dias atuais. Os dois primeiros artigos do código de 1894 ilustram o alcance urbanístico da legislação sanitária:

Artigo $1^{\circ}$ - todas as Ruas nunca deverão ter menos de 16 metros de largura e as avenidas nunca menos de 25 , sempre que a topografia local o permitir: travessa, de pequena extensão podem ser toleradas, com 10 metros de largura.

Artigo $2^{\circ}$ - os passeios das Ruas ocuparão cada um pelo menos o espaço correspondente à sexta parte da largura das Ruas. (São Paulo, 1894)

Nesse momento, os cortiços - forma mais comum de moradia da parcela pobre da população eram considerados vetores de epidemias e "ninhos" de tuberculose. O Código Sanitário já proibia sua existência e estabelecia que as vilas operárias se localizassem longe de áreas centrais.

Foi apenas a partir de 1918, com o médico sanitarista Geraldo Horácio de Paula Souza, enquanto diretor do Serviço Sanitário do Estado de São Paulo, que aconteceriam as primeiras transformações significativas no código. A atuação de Paula Souza estava ancorada no Decreto 3876 de 11 de junho de 1925 que, segundo Campos (2002), reorganizou o serviço sanitário e suas repartições dependentes: criou a Inspetoria de Policiamento Domiciliário, tendo como atribuição fiscalizar habitações para verificar se obedeciam aos critérios de construção expedidos pelo Código Sanitário, e a Inspetoria de Higiene do Trabalho, que, com caráter policial, fornecia "desenvolvimento razoável à questão do trabalho humano nas ocupações industriais”" (Mascarenhas, 1949).

O Código de Edificações do município de São Paulo de 1934 (Código Arthur Saboya), que vigorou por dezenas de anos e serviu de modelo para a elaboração de Códigos de Edificações de diversas outras cidades brasileiras, segue em linhas gerais os princípios urbanísticos previstos no Código Sanitário Estadual de 1894. Nesse sentido, vale destacar sua abordagem sobre os cortiços:

Artigo 193 - entende-se por cortiço o conjunto de duas ou mais habitações que se comuniquem com vias públicas por uma ou mais entradas comuns, para servir de residência para mais de uma família.
Parágrafo $1^{\circ}$ - excetuam-se dessa disposição os hotéis [sic.] e casas de pensão que funcionem com licença da Prefeitura.

Parágrafo $2^{\circ}$ - não se acham também incluídos na categoria de cortiços os prédios de apartamentos que satisfaçam os dispositivos deste código. (Código de Obras Arthur Saboya, 1929, p. 3-4)

Assim, é possível afirmar que as primeiras tentativas para regulamentar o uso e a ocupação do solo em Araraquara foram instrumentalizadas por um conjunto de legislações sanitárias. Esse processo se altera a partir da década de 1950, influenciado por um período de grande desenvolvimento econômico da cidade.

A população de Araraquara tornou-se efetivamente urbana a partir dessa década, ${ }^{6}$ com a implantação de melhorias na infraestrutura urbana (água, esgoto, energia elétrica e asfaltamento das vias públicas); com a instalação de núcleos regionais de administração pública (DER, Secretaria da Fazenda e Contadoria da Estrada de Ferro Araraquara); e com a criação das faculdades de Filosofia, Ciências e Letras, de Química, de Farmácia e de Odontologia. Esses aparatos deram suporte para as indústrias locais, especialmente Lupo Meias S.A. e Nigro Alumínios Ltda., alcançarem projeção nacional. O desenvolvimento do primeiro Plano Diretor de Araraquara está relacionado a dois principais aspectos. Em primeiro lugar, ao enfoque dado à questão urbana no Brasil a partir da década de 1950, e especificamente no estado de São Paulo, que passa a ser encarada como um problema social a ser resolvido pelo Poder Público Municipal. Em segundo, à solidificação de políticas de desenvolvimento urbano, sistematizadas pelo instrumento do planejamento urbano. Na verdade, esse sistema só veio a se institucionalizar a partir da década de 1960, com a criação do Sistema Financeiro Habitacional (SFH) e com instrumentos, como os Planos Diretores de Desenvolvimento Integrado (PDDIs) e a consequente Lei de Uso e Ocupação do Solo, conhecida como zoneamento.

Identificamos, na cidade de Araraquara, um efetivo debate sobre o planejamento urbano a partir de 1950. Os jornais da cidade noticiavam frequentemente os debates promovidos a respeito do desenvolvimento urbano local e a necessidade da elaboração de um plano diretor. Entretanto, a formulação de um instrumento que ordenaria a ocupação e exploração do espaço urbano fez eclodir diversos interesses de indivíduos, entidades e dos próprios condutores do poder público. A análise do processo de elaboração do Plano Diretor de Araraquara evidencia um mo- 
mento complexo de sua história em que os interesses particulares foram explicitados. Por um lado, fica explícita, com a análise desse processo, a abnegação de determinados integrantes das Comissões do Plano Diretor formadas que não deixaram de mover esforços para que a proposta urbanística se concretizasse no município. Por outro lado, também fica patente o caráter oportunista de determinados grupos que acabaram por arrastar, por longos 8 anos - período que compreende a data de publicação da primeira portaria que determinava o início dos trabalhos, Portaria n. 870, de 28 de fevereiro de 1955, até a conclusão do Plano Diretor pelo Arquiteto Rocha Filho no ano de 1963 -, a formalização do primeiro Plano Diretor de Araraquara. Talvez seja essa a característica mais marcante desse processo, ou seja, o processo de elaboração do Plano Diretor colocou às claras a faceta mais secreta e repugnante de Araraquara: uma cidade em que muitas decisões importantes eram definidas nos bastidores da política. Vejamos como se deu esse processo por meio da reconstituição histórica, fundamentada em documentos oficiais resguardados no Arquivo Histórico de Araraquara, desse período que se inicia na década de 1950 e termina na de 1970.

O jornal A Gazeta, em 3 de fevereiro de 1955, dava notícia da posse da nova diretoria da Associação de Engenharia, tendo como presidente Boaventura Gravina e vice-presidente Hermínio Amorim Júnior. $\mathrm{Na}$ ocasião, o presidente revelou o programa que pretendia realizar, dando destaque ao Plano Diretor de Araraquara. Foi o primeiro registro encontrado nos arquivos da imprensa local sobre a necessidade de elaboração de um Plano Diretor.

Segundo informações coletadas em entrevista realizada em 9 de agosto de 2011, com o Prof. Dr. Gustavo Neves da Rocha Filho - arquiteto, urbanista e professor da FAU-USP que conduziu a elaboração do Plano Diretor de Araraquara concluído em 1963 -, Anhaia Mello já tinha estabelecido contato com as lideranças políticas de Araraquara por intermédio do irmão e diretor da FAU, Pedro Gravina.

Segundo Alcyr Azzoni,

coincidiu do Engenheiro Boaventura Gravina ser o presidente do Rotary Club Araraquara, 1955, era o único da cidade, tinha quase uns 60 membros. A nata dos empresários e profissionais de Araraquara, dom comércio, dos serviços. Engenheiro Boaventura Gravina, cultura extrema, empresário, fazendeiro, presidente do Rotary, o irmão, Pedro Gravina, toma posse como diretor da FAU. No mesmo momento, surge o interesse de criar um laboratório para estudos urbanísticos. O Boaventura fala pro [sic.] irmão, e ele estabelece o contato com Anhaia Mello que tenta utilizar Araraquara como o primeiro teste do laboratório. O CEPEU tentou desenvolver o PD [sic.]. (Alcyr
Azzoni, entrevista concedida ao autor em outubro de 2011)

No entanto, a entrevista realizada com a Sra. Vanda Gravina revelou outra hipótese explicativa de como fora estabelecido o contato de lideranças de Araraquara com Anhaia Mello. Na realidade, colhemos informações complementares que redimensionaram o caminho percorrido por Boaventura Gravina no estabelecimento de contato com urbanistas da FAU-USP. O foco ainda se mantém sobre Pedro Gravina, irmão de Boaventura, mas muito provavelmente seu irmão não tenha sido diretor da FAU, fato que não conseguimos comprovar na Faculdade de Arquitetura e Urbanismo. Pedro Gravina era um renomado engenheiro italiano, catedrático das Universidades de Milão e de Roma e que, por conta de sua inserção e de seu renome internacional, já havia estabelecido contato, muito provavelmente, com Anhaia Mello em congressos realizados na Europa. Pedro Gravina retorna ao Brasil já aposentado e, sabendo do interesse do irmão em estimular o desenvolvimento do Plano Diretor de Araraquara, colocou Anhaia Mello em contato.

Rocha Filho afirma que o contato de Anhaia Mello com personalidades locais foi intensa. Em Araraquara, Anhaia Mello conheceu o professor Eli Lopes Meirelles, jurista, que a convite dele o auxiliou na elaboração da Lei de Loteamento de São Paulo e que exprime a base do seu pensamento urbanístico.

Quanto à introdução das concepções urbanísticas de Anhaia Mello em Araraquara, o papel do arquiteto e funcionário público local, Arnaldo $\mathrm{Pa}-$ lamone Lepre, foi decisivo. Lepre havia se formado em arquitetura no Rio de Janeiro, pela antiga Escola Nacional de Arquitetura, depois Universidade Federal de Arquitetura e Urbanismo. Essa Universidade sofria diretamente a influência do pensamento urbanístico de Anhaia Mello. Para Rocha Filho, além de Lepre, os irmãos Barbiere, Nelson e Paulo, também exerceram forte influência na disseminação das concepções urbanísticas de Anhaia Mello. Integrantes da Sociedade dos Engenheiros Residentes em Araraquara (SOENGRA) também tiveram um papel fundamental na disseminação das concepções urbanísticas de Anhaia Mello.

Com esse objetivo, Gravina disse que já havia apresentado a proposta a Luiz Ignácio Anhaia Mello, professor da área de Construções Civis, Arquitetura e Urbanismo, da Escola Politécnica de São Paulo e da FAU-USP. Gravina propôs ao professor Anhaia Mello que aproveitasse os alunos da FAU para, sob sua orientação, elaborar o Plano Diretor de Araraquara. Anhaia Mello respondeu que aquela sugestão tinha vindo ao encontro do que ele efetivamente pretendia fazer no Centro de Pesquisas e Estudos Urbanísticos, 
a ser criado ainda naquele ano. A finalidade do centro seria colaborar com as prefeituras na elaboração dos Planos Diretores nas cidades do Estado de São Paulo.

O então prefeito de Araraquara, engenheiro Antonio Tavares Pereira Lima, se interessou pela proposta em meados de fevereiro de 1955. Desse interesse, resultou uma visita ao professor Anhaia Mello e, posteriormente, a já citada Portaria n. 870 de 28 de fevereiro de 1955, nomeando a Comissão do Plano Diretor de Araraquara, composta por Otto Ernani Muller, Presidente da Câmara Municipal de Araraquara; Engenheiro Boaventura Gravina, Presidente da Associação de Engenharia de Araraquara; Engenheiro Orlando Drumond Murgel, Diretor da Estrada de Ferro de Araraquara; Engenheiro Alberto Maricato, Diretor do Departamento de Estradas de Rodagem; Dr. José Péricles Freire, Diretor do Serviço Especial de Saúde; André Lia, Presidente da Associação Comercial e Industrial; Comendador Hélio Morganti, Delegado Regional da CIESP; Dr. Itamar Calado de Castro, Presidente da Associação Agropecuária; e José Benedito de Carbalho Mello, Presidente do Rotary Club de Araraquara. O presidente da Comissão do Plano Diretor seria o prefeito Engenheiro Antonio Pereira Lima e o Secretário, Boaventura Gravina.

Na Portaria n. 870, de 28 de fevereiro de 1955 , publicada no jornal $O$ Imparcial em $1^{\circ}$ de março de 1955, o real motivo de o plano diretor não ter sido executado no ano de 1952 foi revelado: "no exercício de 1952, estiveram o Executivo e o Legislativo Municipal empenhados, na realização do respectivo $\mathrm{Pla}-$ no, o qual só não tornou realidade, até o momento, por questões de ordem financeira".

Na mesma Portaria n. 870 (1955), os estudos

relativos à elaboração do Plano receberão a preciosíssima colaboração e direção do Prof. Anhaia Mello, DD. Diretor da Faculdade de Arquitetura e Urbanismo, de São Paulo.-

Como podemos verificar no trecho dessa portaria, há uma referência explícita ao professor Anhaia Melo que seria não apenas um colaborador, mas também um dirigente do Plano Diretor a ser elaborado pela Comissão do Plano Diretor de Araraquara.

No Arquivo Histórico do Município de Araraquara, identificamos uma série de ofícios, do número 65/55 ao 74/55, emitidos no dia 2 de março de 1955 e assinados pelo prefeito Antonio Tavares Pereira Lima, mobilizando todas as autoridades acima descritas que representavam suas respectivas entidades na Comissão do Plano Diretor de Araraquara a

recepcionar o ilustre Prof. Anhaia Mello, Diretor da Faculdade de Arquitetura e Urbanismo, de São
Paulo, um dos maiores urbanistas do país, na gare da Estação da Companhia Paulista, às 18,40 horas [sic.], do próximo dia 5. Outrossim, convido-o, também, para tomar parte no jantar que será oferecido, pela Associação dos Engenheiros, ao distinto visitante, às 19,30 horas [sic.], no dia 5, no Grande Hotel, bem como, assistir a conferência que será proferida pelo Prof. Anhaia Mello, no Club "22 de Agosto", às 20, 30 horas [sic.], do mesmo dia, a qual versará sob [sic.] o tema "Plano Regulador de Araraquara". (Ofícios, 1955, do número $65 / 55$ ao $74 / 55$ )

No dia 4 de março de 1955, o jornal O Imparcial divulgava a palestra do professor Anhaia Mello e informava que ela era patrocinada pela Associação de Engenharia de Araraquara. Segundo a mesma notícia, "antes da palestra do ilustre urbanista, será efetuada a solenidade de posse da Comissão do Plano Diretor, nomeada pelo prefeito Pereira Lima". A nota publicada reforçava que, pelo intermédio da Associação de Engenharia de Araraquara, todas as pessoas interessadas estavam convidadas a assistir a "importante conferência”.

No Club 22 de Agosto, em dia 5 de março de 1955, o professor Anhaia Mello proferiu a palestra "Um Plano Diretor para a região de Araraquara" que contou com a cobertura do Jornal O Imparcial. Nela, Anhaia Mello expôs conceitos e discutiu pontos de vista de um plano regulador de caráter regional.

O Conselho Diretor Rotary Club de Araraquara, presidido à época pelo presidente José B. de Carvalho Mello, por meio de carta destinada ao prefeito Antonio Tavares Pereira Lima, datada de 3 de março de 1955, agradecia os convites para "recepcionar o ilustre prof. Anhaia Mello, Diretor da Faculdade de Arquitetura e Urbanismo, de São Paulo e para participar do jantar que a esse ilustre visitante será oferecido pela Associação de Engenharia" de Araraquara.

As análises documentais mostram que ocorreu uma efetiva formalização da comissão do Plano Diretor. Por meio da Portaria n. 875, de 4 de março de 1955, o prefeito Pereira Lima nomeia o professor Francisco Amendola da Silva, diretor da Escola de Belas Artes de Araraquara, para integrar a Comissão do Plano Diretor. O Ofício n. 713/55, de 4 de março de 1955, evidencia que a Câmara Municipal também se manifestava a respeito da formalização da Comissão. Otto Ernani Muller, então presidente da câmara, acusava o recebimento do Ofício GP. n. 65/55 da prefeitura, em que lhe era comunicado que havia sido nomeado membro da Comissão do Plano Diretor e agradecia. A Estrada de Ferro de Araraquara, com o Ofício DO. n. 412, de 30 de março de 1955, assinado pelo seu diretor engenheiro Orlando D. Murgel, formaliza a sua participação como membro da Comissão do Plano Diretor. 
Durante a administração do prefeito Rômulo Lupo (1955-1959), foram realizados os trabalhos preliminares do plano: cadastramento imobiliário, aerofotogramétrico e a elaboração da planta cadastral e planialtimétrica da cidade. Esses dados foram aproveitados para o estudo da nova rede de água e esgotos da cidade. No entanto, não identificamos a atuação da Comissão do Plano Diretor nesse período que se inicia em 1956 e termina em 1960.

De acordo com análises documentais produzidas no Arquivo Histórico do Município de Araraquara, a Comissão do Plano Diretor, de sua nomeação em 1955 somente voltará à mesa de debates, incentivada por Despacho n. 357/60, de 6 de junho de 1960, assinado pelo presidente da Câmara de Vereadores José Welington Pinto, no ano de 1960. Naquela ocasião, ele mostra a necessidade de continuação dos trabalhos do Plano Diretor nos termos da Portaria n. 870, de 28 de fevereiro de 1955, assim como ocorreu com a cidade de Socorro. Em 3 de novembro de 1960, José Galli, presidente da Câmara Municipal, por meio da indicação n. 510/60 feita pelo vereador Wilmo Gonçalves, encaminha o Ofício n. 2713/60, sugerindo ao prefeito Benedito de Oliveira que seja formalizada uma convocação da Comissão de Estudos do Plano Diretor de Araraquara, "para que se reuna [sic.], e ponha em andamento o que até aqui já fez, no sentido de dar à cidade, novos rumos no campo da planificação".

Paralelamente a esse processo de retomada da elaboração do Plano Diretor da cidade pelo poder público, a Associação de Engenharia e o Rotary Club iniciam a mobilização dos debates, trazendo novamente para Araraquara o professor Anhaia Mello para promover outra palestra. Em 3 de novembro de 1960, o jornal $O$ Imparcial publicou um artigo com o título "Professor Anhaia Mello fará conferência sobre o Plano Diretor". Nesse artigo, Anhaia Mello retomou o tema na cidade de Araraquara, apresentando a necessidade do desenvolvimento de uma regulamentação de uso e ocupação do solo que assumisse um caráter regional. Ele deu destaque aos problemas gerados pelo crescimento acelerado das cidades brasileiras e apontou como alternativa a construção de planos diretores regionais de urbanismo. Também apresentou as exigências legais no Estado de São Paulo, que colocava como obrigatória a elaboração de Planos Diretores nas cidades. Na década de 1960, já era de conhecimento dos pesquisadores da área do urbanismo que uma nova legislação sobre a necessidade de desenvolvimento de Planos Diretores seria instituída no Estado de São Paulo. Em 1967, a então Lei Orgânica dos Municípios (Lei n. 9.842/67, posteriormente alterada pelo Decreto Lei Complementar n. 9 de 31 de dezembro de 1969) determinava a obrigatoriedade da elaboração de plano diretor - então denominado Plano Diretor de Desenvolvimento Integrado
(PDDI) - a todos os municípios paulistas. Estabelecia, ainda, punição aos municípios faltosos, determinando a proibição de auxílio financeiro do Governo do Estado. Os planos diretores foram amplamente desenvolvidos no Estado de São Paulo pelo Centro de Estudos e Pesquisas de Administração Municipal (CEPAM), hoje Fundação Prefeito Faria Lima.

$\mathrm{O}$ prefeito Benedito de Oliveira acolhe a indicação $510 / 60$, de 24 de outubro de 1960 , e com o Ofício GP. n. 115/61, de 9 de fevereiro de 1961, informa à Câmara Municipal que, tão logo fosse reorganizada a Comissão de Estudos do Plano Diretor de Araraquara, seria convocada para o reinício dos trabalhos.

As análises apontam que, a partir de meados de 1961, ocorreu uma efetiva colaboração do Centro de Pesquisa e Estudos Urbanísticos, da Faculdade de Arquitetura e Urbanismo da Universidade de São Paulo (CEPEU-FAU), no assessoramento jurídico para a formalização de estrutura local de planejamento para a elaboração de um Plano Diretor. Chega até as mãos do prefeito Benedito de Oliveira a publicação do CEPEU-FAU n. 9 de julho de 1960 que tratava da "Organização Comunitária para o Planejamento". Segundo esse documento, o Centro de Pesquisa e Estudos Urbanísticos recebia numerosas solicitações para colaborar com a preparação de planos diretores e outros estudos. Diversos municípios do Estado de São Paulo "vêm-se [sic.] interessando ùltimamente [sic.] pelo planejamento de seu desenvolvimento". Nesse documento ainda consta:

torna-se evidente que um novo campo profissional, integrado nas administrações municipais, está surgindo. Dentro de poucos anos teremos condições excelentes para que as atividades de planejamento municipal se desenvolvam em alto nível, produzindo desta forma, resultados de grande utilidade aos administradores do interior. (CEPEU-FAU n. 9 de julho de 1960)

Entretanto, o Centro de Pesquisa e Estudos Urbanísticos atentava para a "grande deficiência de pessoal habilitado para desempenhar tarefas de planejamento. Embora já se possam contar com dezenas de técnicos dedicando-se ao problema, êsse [sic.] número é ainda insuficiente para atender às necessidades de nosso interior" (CEPEU-FAU n. 9 de julho de 1960). Mesmo contando com essa "deficiência" técnico-profissional, "muito material pode ser preparado desde já, contando apenas com a colaboração de elementos locais, desde que devidamente orientados" (1960, p. 1). Por esse motivo, o CEPEU-FAU promoveu a divulgação de um modelo de anteprojeto de lei nas prefeituras do interior com o objetivo de que se criasse, em cada município, uma estrutura local de planejamento. $\mathrm{O}$ anteprojeto era produto das últimas 
conclusões tiradas da experiência do CEPEU-FAU e havia sido examinado pelo seu consultor jurídico. Esse documento elaborado pelo CEPEU-FAU, mais tarde, servirá de base para a elaboração do Projeto de Lei n. 168/61 que constituirá a Comissão do Plano Diretor do Município, encaminhado pelo presidente da Câmara Municipal, Herminio Pagotto, ao Executivo.

O Projeto de Lei n. 168/61 foi sancionado pelo Executivo e deu origem à Lei n. 1077, de 9 de dezembro de 1961, constituindo a Comissão do Plano Diretor do Município e deu outras providências que, em certa medida, dificultaram o desmantelamento da comissão como havia ocorrido no passado.

$\mathrm{O}$ artigo $1^{\circ}$ instituía a Comissão do Plano Diretor presidida pelo prefeito que, por sua vez, nomearia de 11 a 15 membros indicados pelas entidades de classe e associações cívicas ou culturais existentes no município, além de representantes da câmara e da prefeitura. Segundo o inciso $1^{\circ}$, ficou a cargo da comissão eleger a sua primeira diretoria para dar andamento às atividades necessárias à elaboração do Plano Diretor. $\mathrm{O}$ inciso $2^{\circ}$ apontava que o caráter do membro da comissão era de caráter cívico, gratuito e de serviço relevante, exercido por 6 anos, no mínimo, renovável bienalmente, pelo terço, sendo que era permitida a recondução.

No inciso $3^{\circ}$, a comissão se resguardava daquilo que, provavelmente, teria sido um dos motivos das desmobilizações passadas, ou seja, o abandono de membros da comissão de elaboração do Plano Diretor: aquele que deixasse de comparecer a três reuniões consecutivas ou de emitir parecer em assunto sujeito à sua consideração por mais de 30 dias, sem justificativa aceita pela comissão, perderia automaticamente o mandato e deveria ser substituído dentro de 20 dias.

No artigo $3^{\circ}$, constam as competências da comissão:

I - emitir parecer sobre todo o projeto de lei ou medida administrativa de caráter urbanístico, ou relacionados com os serviços de utilidade pública do Município, acompanhado do autor, se for medida proposta pelo legislativo;

II - promover estudos e divulgação de conhecimentos urbanísticos e especialmente do Plano Diretor do Município;

III - elaborar o seu regimento interno e realizar os seus trabalhos, observados os seguintes princípios:

a) realização de, pelo menos, uma reunião por mês;

b) deliberação por maioria absoluta;

c) registro, em ata e arquivos adequados, de todas [sic.] as deliberações, pareceres, votos, plantas e demais trabalhos da Comissão e de seus técnicos; d) publicidade de suas reuniões e de seus trabalhos.

(Lei n. 1077, de 9 de dezembro de 1961)

Essas competências dotavam a comissão de certa autonomia na condução dos trabalhos. No entanto, ainda ficava a dúvida se ela conseguiria realizar as atividades sem que, no mínimo, fosse montada uma estrutura administrativa. E é nesse quesito que se inserem os artigos seguintes. $\mathrm{O} 4^{\circ}$ artigo fixava um prazo de 30 dias para a comissão iniciar os seus trabalhos, a partir da nomeação dos seus membros. Com o intuito de impedir uma avalanche de projetos de lei que pudessem alterar a configuração que a cidade assumira até então, o Parágrafo Único instituía que

desde a instalação da Comissão nenhum projeto de lei ou medida administrativa referentes a zoneamentos, arruamentos, loteamentos, construções, espaços verdes, obras e serviços de utilidade pública poderá ser aprovado ou executado, sem prévio parecer da Comissão do Plano Diretor do Município. (Lei n. 1077, de 9 de dezembro de 1961)

Com relação à infraestrutura administrativa para o início dos trabalhos, o artigo $5^{\circ}$ criava o Escritório Técnico junto ao gabinete do prefeito, incumbido da elaboração do Plano Diretor, submetidos à coordenação de um engenheiro ou arquiteto. No inciso $2^{\circ}$, há a caracterização dos colaboradores especializados em problemas relacionados ao planejamento municipal que atuariam em parceria com o Escritório Técnico, tais como: agrônomos, sociólogos, advogados e economistas.

No artigo $6^{\circ}$, as competências do Escritório Técnico são elencadas:

a) estudar todos os assuntos relacionados com o planejamento territorial do município;

b) encaminhar os pareceres técnicos emitidos sobre os assuntos estudados à Comissão do Plano para a conveniente solução;

c) manter permanente contato com o Centro de Pesquisas e Estudos Urbanísticos por intermédio do arquiteto coordenador, para receber orientação geral dos trabalhos. (Lei n. 1077, de 9 de dezembro de 1961)

Ficaria sob responsabilidade da prefeitura, segundo o artigo $7^{\circ}$, o fornecimento ao Escritório Técnico de "funcionários, local, material e demais meios necessários à realização de seus trabalhos, dentro da verba que fôr [sic.] destinada, em cada exercício, no orçamento do Município, ao Plano Diretor". 7 O artigo $9^{\circ}$ reforçava a necessidade de que a elaboração e a execução do Plano Diretor deveriam ser orien- 
tadas pelo Centro de Pesquisa e Estudos Urbanísticos mediante convênio. Essa era uma orientação que constava no modelo de projeto de lei fornecido pelo CEPEU-FAU. O próprio artigo $9^{\circ}$ dessa mesma lei previa que, se houvesse a necessidade de contratação de especialistas, a prefeitura poderia fazê-lo. Assim, abria-se a possibilidade de uma efetiva participação de técnicos da CEPEU-FAU na elaboração de determinadas etapas do Plano Diretor. No dia 12 de dezembro de 1961, a Lei n. 1077 foi publicada no jornal O Imparcial, tornando público o início dos preparativos para, finalmente, ser elaborado o Plano Diretor de Araraquara.

Em 17 de fevereiro de 1962, o professor Anhaia Mello falou ao Rotary Club de São Paulo sobre "Planejamento dos municípios - um novo tema para os serviços rotáricos", defendendo a ideia de os Rotary Clubs liderarem campanhas para a elaboração dos Planos Diretores de suas cidades. Ele afirmou que "todo governo deve ter um programa; todo programa deve ser planejado. Um Plano Diretor ou Regulador do desenvolvimento é indispensável para todo município brasileiro" e que "esse plano se estrutura através de 3 etapas: 1) a de eclosão; 2) a de projeto; e 3) a da execução". Em 6 de abril de 1962, o prefeito Benedito de Oliveira oficializa a formação da Comissão do Plano Diretor e, no dia 19 de abril desse mesmo ano, baixa a Portaria n. 1382 com a nomeação dos membros da Comissão do Plano Diretor do Município de Araraquara, conforme se verifica no quadro abaixo.

Quadro 1 - Relação dos componentes da Comissão do Plano Diretor do Município de Araraquara e entidades que representavam em 1962

\begin{tabular}{|l|l|}
\hline Nome & Entidade que representa \\
\hline José Wellington Pinto & Câmara Municipal de Araraquara \\
\hline Arnaldo Palamone Lepre & Prefeitura Municipal \\
\hline Cônego Aldomiro Storniolo & Vigário da Matriz de São Bento \\
\hline Alceu Di Nardo & $\begin{array}{l}\text { Ordem dos Advogados (Sec. } \\
\text { Araraquara) }\end{array}$ \\
\hline Orlando Mantese & Estrada de Ferro de Araraquara \\
\hline Alfredo de Carvalho & $\begin{array}{l}\text { Departamento de Estradas de } \\
\text { Rodagem }\end{array}$ \\
\hline Jair Bernardes da Silva & Serviço Especial de Saúde \\
\hline José Henrique Albiero & Associação de Engenharia \\
\hline Youhanna Sabbag & $\begin{array}{l}\text { Associação de Medicina - Sec. } \\
\text { Reg. de Araraquara }\end{array}$ \\
\hline Roberto José Fabiano & Associação Comercial e Industrial \\
\hline Paulo Guimarães Fonseca & $\begin{array}{l}\text { Faculdade de Filosofia, Ciências } \\
\text { e Letras }\end{array}$ \\
\hline João Campos Santos & Casa da Lavoura \\
\hline Boaventura Gravina & Rotary Club [sic.] \\
\hline José dos Santos & Lions Club \\
\hline
\end{tabular}

Fonte:Arquivo Histórico de Araraquara, Processo n. 775/55 de $1^{\circ}$ de março de 1995.
Com o propósito de formalizar o compromisso da comissão com a execução dos trabalhos de elaboração do Plano Diretor, foi firmado um Termo de Compromisso no dia 21 de maio de 1962, às 17 horas, no gabinete do prefeito, com a assinatura do professor da FAU-USP Anhaia Mello como testemunha. Os componentes da Comissão do Plano Diretor do $\mathrm{Mu}-$ nicípio de Araraquara e as entidades que representavam em 1962, perante as testemunhas, "prestaram o compromisso de bem e fielmente desempenharem as funções de Membros da referida Comissão". 8 A presença em Araraquara do professor Anhaia Mello foi constante durante os procedimentos de formatação da Comissão do Plano Diretor.

A referência constante nos documentos analisados no Rotary Club é justificada pelo fato de tanto Boaventura Gravina quanto Anhaia Melo serem rotarianos.

Além desse fato, para Alcyr Azzoni,

a composição do Rotary tinha, por exemplo, Nelson Barbieri, Engenheiro, Paulo Barbieri, arquiteto [sic.]. Então a composição do Rotary [sic.], a diversidade dos componentes revelava que era o único local que reunia um grupo com perfil profissional capaz de pegar [sic.] aquele material e revisar alguma coisa. (Alcyr Azzoni, entrevista concedida ao autor em outubro de 2011)

Segundo Azzoni, os integrantes do Rotary eram empresários poderosos e atuavam efetivamente nas Comissões do Plano Diretor como, por exemplo, Aldo Lupo, Wilton Lupo, Elvio Lupo, empresários-industriários com atuação em diversos setores da economia.

Era quase uma maçonaria, todos eles também deviam ser maçons. Tinham o lado oculto, como maçons, e o de serviços, no Rotary Club Araraquara composto por profissionais. Só entra no Rotary quem representa uma profissão. A praxe do Rotary é, primeiramente convidar a pessoa para dar uma palestra, depois para fazer parte do Club.

Boaventura Gravina era um Rotariano entusiasta. Segundo a Sra. Vanda Gravina,

ele fundou o Rotary de Brasília. Ele foi pra lá [sic.], conversou com diversas pessoas interessadas e ele [sic.] fundou o Rotary de Brasília. No ano que ele foi Governador do Rotary ele fundou 11 Clubs. Ele era muito dinâmico, ele fazia as coisas acontecerem. Por exemplo, ele foi para o Paraná, não me lembro

8. Prefeitura Municipal de Araraquara. Processo n. 775/55, de $1^{\circ}$ de março de 1995. Termo de Compromisso lavrado em 21 de maio de 1962, formalizando a Comissão do Plano Diretor de Araraquara. 
porque, e comprou uma fazenda lá [sic.], depois uma em Mato Grosso, porque nós fomos representar presidentes de Rotary duas vezes no Mato Grosso. Depois dessa visita, ele acabou abrindo duas fazendas lá [sic.]. (Vanda Gravina, entrevista concedida ao autor em outubro de 2011)

A documentação relativa à fundação do Rotary Club em Araraquara se perdeu. Entretanto, em uma publicação comemorativa dos 70 anos do rotary em São José do Rio Preto, constam alguns dados acerca do Rotary Araraquara, tais como a sua fundação em 29 de novembro de 1935. Segundo Gilberto Scandiuzzi, do Rotary Club de São José do Rio Preto,

o livro de atas do nosso Club, cuja $1^{\text {a }}$ reunião, de instalação e posse do Conselho Diretor, ocorreu em 4 de dezembro de 1935, com a presença de representantes do Club padrinho Araraquara. Consta da ata que sentaram-se à mesa "os hóspedes ${ }^{9}$ rotarianos do Club de Araraquara Joaquim Vieira dos Santos, Rômulo Lupo, Mauro Rodrigues e Bento Braga Filho", os três primeiros respectivamente presidente, tesoureiro e vogal daquele Club... (o último, vice-presidente) [sic.]. Todos assinaram a ata de fundação do Club. (Rotary Club Araraquara, s.d.; grifos nossos)

No final de 1948, o engenheiro Boaventura Gravina, após retornar de sua viagem aos Estados Unidos e ao Canadá, em comitiva composta por engenheiros e industriais, da qual faziam parte vários sócios do Rotary Club de São Paulo, sensibilizado pela troca de ideias que mantinha com industriais e homens de negócios em Araraquara, imaginou a (re)fundação do Rotary Club em Araraquara. ${ }^{10}$ A iniciativa de Gravina encontrou ressonância, contando com o apoio do Hélio Morganti, proprietário da Usina de Açúcar Tamoio, e de Germano Schuster, rotariano militante do Rotary Club de Limeira, que havia residido durante muito tempo em Araraquara, inicia as conversações para a (re)fundação do Rotary Club de Araraquara. Germano Schuster ficou encarregado de contatar o Rotary Club de Limeira, então presidido por Victor D'Andrea, e, destes contatos, resultou um encontro marcado para o dia 20 de fevereiro de 1949, realizado nas dependências da Usina Tamoio. Na reunião estiveram presentes o governador do Distrito 41, Ariovaldo de Barros Camargo; os rotarianos de Limeira, Victor D’Andrea, Germano Schuster e João Machado; e os futuros rotarianos de Araraquara, Hélio Morganti,
Boaventura Gravina, Luiz Bento Palamone, Gennaro Granata, Procópio de Oliveira, José de Salles Gadelha e José da Motta Cerqueira. Naquela ocasião, ficou decidido que cada um deles convidaria outros elementos para constituir o futuro Rotary Club de Araraquara e estes seriam considerados os fundadores.

O Rotary, criado como associação em 1910, constituiu-se como organização internacional mediante uma dotação de capital a fundo perdido, feita de acordo com as leis do Estado de Illinois. O Código Moral Rotariano foi aprovado no congresso realizado em Saint Louis, em 1928, e, de acordo com Gramsci (2001), tem como princípio o fato de o Rotary ser fundamentalmente uma filosofia de vida, da vida que busca conciliar o eterno conflito existente entre o desejo de ganho pessoal e o dever e consequente impulso de servir ao próximo. Esta filosofia é a filosofia do serviço: dar de si antes de pensar em si, baseada no princípio moral de que quem serve melhor ganha.

Rotary Club é um grupo de homens de negócio e de profissionais liberais, os quais, sem juramentos secretos nem dogmas ou credos, [...] aceitam a filosofia do serviço. (Gramsci, 2001, p. 297)

Segundo o autor, dos 2.639 "Clubs" rotarianos existentes (no momento da publicação do artigo), 2.088 estavam nos EUA, 254 na Inglaterra, 81 no Canadá, 18 na Itália, 13 na França, 1 na Alemanha, 13 na Espanha, 19 no México, 15 na Austrália e muito menos em outros países. Além disso, o Rotary Club, para Gramsci (2001), é uma superação orgânica da maçonaria e representa interesses mais concretos e mais precisos. A característica fundamental da maçonaria é a democracia pequeno-burguesa, o laicismo, o anticlericalismo etc. Já o Rotary é uma organização das classes altas e seus componentes só se dirigem ao povo indiretamente.

Em Araraquara, o Rotary Club se envolveu diretamente com o processo de elaboração do Plano Diretor local. Naquele momento, representava a possibilidade de superação do denominado capitalismo selvagem que, em sua versão especulativa imobiliária, poderia levar a cidade de Araraquara ao caos urbano. A proposta filosófica do Rotary era a da instalação de um novo costume, mais favorável ao desenvolvimento das forças econômicas. A sua característica heterogênea na composição, ou seja, o fato de a sua origem não ser confessional nem maçônico, contribuía com uma diversificação de seus quadros.

9. A respeito dos dois principais fundadores do Rotary em Araraquara, em 1935, vale destacar que Joaquim Vieira dos Santos era hortifruticultor na cidade e havia sido beneficiado com a isenção do consumo de meia polegada de água por 5 anos em 1932 . A isenção tinha como fundamento, em diversos requerimentos encaminhados ao Legislativo Municipal, o seu consentimento pela passagem de tubos condutores de água para atender a parte da cidade hoje denominada Vila Xavier. Rômulo Lupo pertencia à família de industriários locais e, na década de 1950, se tornaria prefeito de Araraquara e um entusiasta do desenvolvimento do Plano Diretor.

10. Sobre o assunto, conferir o sítio disponível em: <http://www.nossosaopaulo.com.br/Rotary/4540/Araraquara/Rotary_Historia.htm> 
Assim, em um momento em que a sociedade civil contava com poucas possibilidades de composição de suas forças de pressão, o Rotary, por essas particularidades, fez a diferença no cenário local, foi o condutor natural do processo de formação das Comissões do Plano Diretor de Araraquara. Por outro lado, o caráter técnico que o Plano Diretor demandava, já inclusive ressaltado por Anhaia Mello, não poderia ser suprido pelos quadros do funcionalismo público da prefeitura de Araraquara. Nesse cenário de carências técnicas é que também atuou a AAEAA, uma associação de classe organizada no Estado de São Paulo, que contava com muitos membros formados pela própria FAU-USP, com os conhecimentos suficientes para suprir as necessidades técnicas de elaboração do Plano Diretor local, finalizado em 1963, assim como todo o seu processo de atualização e incorporação ao rito administrativo da prefeitura durante a década de 1970.

\section{Considerações finais}

A recomposição histórica do processo da finalização do Plano Diretor de Araraquara somente pode ser elaborada por iniciarmos nossas análises em um período anterior, ou seja, na década de 1950. É nessa década que a cidade enfrentou desafios quanto ao seu desenvolvimento urbano que fizeram com que o Plano Diretor deixasse de ser uma mera honraria, que classificaria a cidade como moderna, e passasse a ser uma necessidade. Entretanto, essa necessidade se chocava com interesses de grupos que, nitidamente, atravancavam os trabalhos das inúmeras comissões para a elaboração do Plano Diretor que foram criadas nos 14 anos de debates e produção de levantamentos sobre a cidade. Na tentativa de romper com as amarras que faziam com que o Plano Diretor de Araraquara não deslanchasse, a prefeitura entrou em contato com a prefeitura de Taubaté para que esta fornecesse informações sobre o processo de elaboração de seu Plano Diretor.

Em 6 de junho de 1962, Benedito Olegário R. Nogueira de Sá, chefe de gabinete do prefeito, envia uma carta ao prefeito Benedito de Oliveira informando que o Plano Diretor de Taubaté encontrava-se publicado na revista Politécnica n. 173, de 1957.

Segundo Neves da Rocha, o diretor do CEPEU, Lauro Birkholz, convocou representantes das prefeituras que, no passado, já haviam estabelecido contato com o órgão. Nessa reunião, Neves da Rocha estabeleceu contato com Lepre que o informou que a etapa de diagnóstico do Plano Diretor já havia sido cumprida, faltava apenas a formulação do plano. Em
1962, Benedito de Oliveira, prefeito de Araraquara, reuniu-se com Neves da Rocha e solicitou que conversasse com lideranças locais sobre a necessidade de formulação do plano e que apresentasse propostas para sua finalização. ${ }^{11}$

Em 17 de janeiro de 1963, pelo Edital 367/63 publicado no jornal $O$ Imparcial, foi aberta a concorrência pública de elaboração do Plano Diretor do Município de Araraquara, com verba da Câmara Municipal para o processo licitatório. O prazo para a entrega das propostas expirava em 11 de fevereiro de 1963. O Plano Diretor deveria ser concluído até 20 de dezembro do mesmo ano.

Com o intuito de dar credibilidade aos preparativos de elaboração do Plano Diretor de Araraquara, houve a tentativa de o prefeito Benedito de Oliveira envolver pesquisadores do Centro de Pesquisa e Estudos Urbanísticos da FAU-USP na direção do processo de escolha dos profissionais que elaborariam o estudo sobre a cidade. No Ofício n. 42/63, de 15 de fevereiro de 1963, consta que o professor Lauro Bastos Birkholz, diretor do CEPEU, recusou a incumbência de ser o presidente da comissão julgadora da concorrência para a elaboração do Plano Diretor. Ele afirmou que, embora estivesse honrado com o convite, só poderia participar do julgamento como simples membro da comissão julgadora, em virtude de impedimentos de natureza ética, tal como o fato de os concorrentes serem profissionais que, em suas atividades no campo do planejamento, sempre estiveram ligados ao CEPEU por ele dirigido. Birkholz sugeriu que a própria comissão do Plano Diretor, já instituída legalmente, julgasse a concorrência e que o presidente da comissão julgadora poderia ser o seu vice-presidente, ou seja, Boaventura Gravina.

Exigiu-se que o vencedor da concorrência instalasse escritório em Araraquara a fim de evitar que fosse elaborado um plano "friamente", à distância. A proposta era que, com a elaboração do Plano Diretor, as linhas mestras do progresso de Araraquara fossem traçadas. A atualização do plano ficaria a cargo da Comissão do Plano Diretor e de escritório técnico ligado aos poderes públicos com caráter de assessoramento. Assim, para a realização desses trabalhos, foi montado um escritório técnico da comissão de elaboração do estudo urbanístico com o aluguel da sala 41, do $4^{\circ}$ andar do Edifício Bradesco, na Rua São Bento, de propriedade de Clodoaldo Medina, por 7 meses.

$\mathrm{O}$ artigo publicado pelo Jornal O Imparcial, de 22 de janeiro de 1963, marca esse acontecimento nos seguintes termos:

Estamos às vésperas do planejamento do futuro do nosso município: o trabalho que encetamos há oito 
anos está no limiar de sua realização. Fazemos votos para que o Plano vencedor seja fantasioso sem ser fantástico e arrojado, sem ser utópico, conciliando nossa tradição com os tempos modernos e o passado, com o futuro: Plano para uma civitas e não para uma urbs. (Jornal O Imparcial, 1963, p. 6)

Também nesse mesmo ano, em 11 de fevereiro, realizou-se no gabinete do prefeito Benedito de Oliveira a abertura das propostas recebidas, com a presença de autoridades locais, de membros da Comissão do Plano Diretor e de representantes do CREA, 6 região. Pela Portaria n. 1497, de 20 de fevereiro de 1963, o prefeito designou uma comissão para analisar as propostas, constituída pelo arquiteto Paulo Camargo de Almeida, da Escola de Engenharia de São Paulo, pelo professor Roberto Cerqueira César, da Faculdade de Arquitetura e Urbanismo da USP, e pelo engenheiro Boaventura Gravina, membro da Comissão do Plano Diretor. Por decisão unânime, foi escolhida a proposta apresentada pelo arquiteto Gustavo Neves da Rocha Filho, que na sua equipe contava com técnicos de reconhecida capacidade profissional. No contrato constava o prazo de oito meses para a elaboração do Plano Diretor, que foi rigorosamente cumprido: ele foi entregue em 22 de dezembro de 1963. Durante a execução do plano, o prefeito Benedito de Oliveira cedeu à comissão um conjunto de salas no Edifício Bradesco, para a realização de debates de assuntos ligados ao plano e para o estudo de outros que fossem importantes para os trabalhos, entre os quais a mudança da Estação Ferroviária de Araraquara. Após três administrações municipais, o Plano Diretor foi entregue. As discussões iniciaram-se no governo do prefeito substituto Otto Ernani Muller, em 1955, em virtude do afastamento do prefeito Antonio Tavares Pereira Lima, em 1954. Avançaram pelo primeiro mandato do prefeito Rômulo Lupo (1956-1959) e pelo mandato do prefeito Benedito de Oliveira (1960-1963).

Rocha Filho, em editorial publicado no dia 21 de novembro de 1963, no Jornal O Imparcial, ${ }^{12}$ afirma que a ideia

fundamental no Plano Diretor de Araraquara é a setorização. Cada setor constitui uma unidade de vizinhança cuja população máxima será da ordem de 10.000 habitantes. Esses setores em número de 22 têm a mesma função das superquadras de Brasília. (Jornal O Imparcial, 1963, p. 6)
Neves da Rocha, em entrevista, afirmou que Boaventura Gravina pouco participou das reuniões de elaboração do Plano Diretor, assim como os demais membros da comissão, e que não houve a participação de associações nessa etapa, "a elaboração do plano foi um trabalho solitário". Os trabalhos de $\mathrm{Ne}-$ ves da Rocha se resumiram no fornecimento de material para todo o município, com a criação de mapas temáticos que orientariam as intervenções na malha urbana. Ele elaborou um planejamento para o município, e não apenas para a cidade de Araraquara, para um período de 25 anos. O plano, para Rocha Neves, apresentou diretrizes gerais que deveriam servir de orientação ao procedimento de intervenção urbana a partir daquele momento.

O Memorial Descritivo do Plano Diretor elaborado por Rocha Filho previa ainda que cada setor fosse delimitado por vias principais de trânsito rápido, com largura de 25 metros, duas pistas e canteiro central. No interior do setor, permaneceriam as ruas com 12 metros, destinadas ao tráfego local. Dessa forma, ele argumentava, não haveria necessidade de alargamento das ruas da cidade, permanecendo com seus três metros para possibilitar o plantio de árvores. Todos os setores teriam como centro uma escola primária e "as crianças poderiam atravessar as ruas de movimento". Segundo Rocha Filho, a delimitação dos setores foi feita para que uma criança não precisasse, na situação mais desfavorável, caminhar mais de 600 metros para chegar à escola. Após definir as zonas residenciais e comerciais, o plano fixava um perímetro de expansão que permitiria o abrigo de 300.000 habitantes, número de referência para a população de Araraquara no ano de 1990, com a utilização de 100.000 automóveis. ${ }^{13}$

Por esse motivo, a viabilidade de execução do plano estava justamente no fato de a escolha do sistema de vias principais ter recaído em ruas já com largura suficiente para que pudessem ser alargadas sem grandes despesas de desapropriação. O Plano Diretor estava acompanhado pelo projeto de novo código denominador das Normas Urbanísticas dividido em cinco tópicos: Normas Administrativas; Normas de Zoneamento; Normas Gerais para as Construções; Normas para a Execução das Construções e Normas para os Loteamentos. Dessa forma, o Plano Diretor constituía-se de Normas Técnicas (plano de utilização do solo, do sistema viário, de zoneamento, espaços verdes etc.) e de Normas Jurídicas (Código de Obras ou Normas Urbanísticas). habitantes. O censo de veículos em 2004 apresentou uma frota de 52.546 automóveis; 2.524 caminhões; 645 tratores-caminhão; 2.092 caminhonetes; 273 micro-ônibus; 15.913 motocicletas; 729 ônibus; e 5 tratores de rodas, o que perfaz um total de 75.960 veículos. Essas informações estão disponíveis em: <http://www.ibge.gov.br/cidadesat/default.php>. Acesso em: 3 de ago. 2011. Portanto, os números propostos para o ano de 1990 pelo Plano Diretor de Araraquara, finalizado em 1963, estavam superestimados, tendo em vista os censos do IBGE de 1991, 2004 e 2005. 
O Jornal O Imparcial, em 27 de dezembro de 1963, publicou artigo em que Rocha Filho concluía o processo de elaboração do Plano Diretor de Araraquara:

\begin{abstract}
Araraquara com a aprovação deste Plano poderá ufanar-se de ser, e agora com maior razão, a pioneira nas realizações urbanísticas. Podemos fazer esta afirmação sem receio de críticas porque a nós, autores do projeto, não cabe a glória de tê-lo realizado; que se tudo estava feito e a própria Comissão do Plano, nestes oito meses muito nos ajudou. Mas será a instituição deste projeto por lei, por vontade e livre arbítrio dos vereadores desta cidade, que irá fazer de Araraquara uma cidade tão moderna quanto Brasília. O nosso trabalho, fácil de realizar, não tem nenhum mérito: ele representa o mínimo que um profissional deve fazer; e nós fizemos como um médico que examina um doente e fornece uma receita. Cabe ao cliente tomar o remédio. (Jornal $O$ Imparcial, 1963, p. 7)
\end{abstract}

As atividades iniciais de elaboração do plano se encerraram em dezembro de 1963 com a entrega do memorial descritivo elaborado pelo arquiteto Rocha Filho. Durante mais de dois anos o processo de elaboração ficou estagnado nessa fase, concluída com a entrega do memorial.

Em 1964, a cidade de Araraquara entra na segunda gestão de Rômulo Lupo, eleito por uma coligação de partidos que abrigavam políticos egressos do janismo. Bizelli (1990) afirma que, quanto ao planejamen- to, Rômulo Lupo, em sua gestão, empenhou todo o seu esforço para que o instrumento Plano Diretor não se efetivasse, procurando desmoralizar a comissão que o subscrevia.

Neves da Rocha afirmou que, após a entrega do plano já no segundo mandato de Rômulo Lupo, foi convidado a se reunir com esse prefeito, que lhe disse:

O Plano Diretor que o senhor elaborou está aqui em minha gaveta. Não encaminhei para a Câmara, pois acredito que Araraquara necessita de desenvolvimento e esse plano o limita. Eu quero construir um hotel em Araraquara para receber empresários da capital. Também pretendo construir um prédio de escritórios para abrigar os representantes de empresas da capital e um ginásio de esportes para atrair os jogos estaduais. Todas essas ações trarão desenvolvimento para Araraquara e entram em conflito com o que é proposto no plano elaborado. (Gustavo Neves da Rocha Filho, entrevista concedida ao autor em 9 de agosto de 2011)

Neves da Rocha ainda afirmou que apoiou as iniciativas de Rômulo Lupo por acreditar que realmente a cidade precisava se desenvolver. O plano de desenvolvimento de Lupo foi aprovado pelo planejador e urbanista e, a partir desse momento, Lupo entrou em conflito com a comissão do Plano Diretor, impregnada dos pressupostos limitadores do crescimento urbano elaborados por Anhaia Mello e que serviam de inspiração teórica para o processo de formulação do Plano Diretor finalizado em 1963.

\section{Referências}

BENINCASA, V. Velhas fazendas: arquitetura e cotidiano nos campos de Araraquara, 1830-1930. São Carlos: EdUFSCar; São Paulo: Imprensa Oficial do Estado, 2003. BIZELLI, J. L. O planejamento municipal e o poder local em Araraquara. Dissertação (Mestrado) - Faculdade de Ciências e Letras da Universidade Estadual Paulista Júlio de Mesquita Filho, Campus de Araraquara, 1990.

CAMPOS, C. de. São Paulo pela lente da higiene: as propostas de Geraldo de Paula Souza para a cidade (1925-1945). São Carlos, SP: RiMa, 2002.

CARTA DE ATENAS, 1955. Disponível em: <http// www.icomos.org.br>. Instituto do Patrimônio Histórico e Artístico Nacional (IPHAN). Acesso em: 2 mar. 2011. CEPEU-FAU n. 9 de julho de 1960 que tratava da "Organização Comunitária para o Planejamento".

CÓDIGO DE OBRAS ARTHUR SABOYA DE 1929.

Lei n. 3.427. Revisado e consolidado pelo Ato n. 663, de 10 de agosto de 1993. p. 3-4.
FICHER, S. Os arquitetos da Poli: ensino e profissão em São Paulo. São Paulo: FAPESP, Ed. USP, 2005.

GRAMSCI, A. Cadernos do cárcere: temas de cultura, ação católica, americanismo e fordismo. Rio de Janeiro: Civilização Brasileira, 2001.

HOBSBAWM, E. A era do capital. Rio de Janeiro: Paz e Terra, 1979.

IBGE. Perfil dos municípios brasileiros 1999. Rio de Janeiro: Instituto Brasileiro de Geografia e Estatística, 2001a. Perfil dos municípios brasileiros. Rio de Janeiro: Instituto Brasileiro de Geografia e Estatística, 2001b. Indicadores de desenvolvimento sustentável. Brasil, 2002.

Perfil dos municípios brasileiros: gestão pública 2001. Rio de Janeiro: Instituto Brasileiro de Geografia e Estatística, 2003.

Perfil dos municípios brasileiros: gestão pública 2001. Rio de Janeiro: Instituto Brasileiro de Geografia e 
Estatística, 2005.

Perfil dos municípios brasileiros: gestão pública 2001. Rio de Janeiro: Instituto Brasileiro de Geografia e Estatística, 2008.

KERBAUY, M. T. M. A morte dos coronéis: política interiorana e poder local. São Paulo: Cultura Acadêmica, 2000.

MASCARENHAS, R. S. Contribuição para o estudo da administração sanitária estadual em São Paulo. Tese (Doutorado) - Faculdade de Higiene e Saúde Pública da USP, São Paulo, 1949.

ROTARY CLUB ARARAQUARA. Nossa história: projeto memória do Club. Disponível em: <http://www. nossosaopaulo.com.br/Rotary/4540/Araraquara/Rotary_ Historia.htm>. Acesso em: 12 fev. 2011.

TELAROLLI JÚNIOR, R. Poder e saúde: a república, a febre amarela e a formação dos serviços sanitários no Estado de São Paulo. Campinas: Faculdade de Ciências Médicas/Universidade Estadual de Campinas, 1993.

\section{Fontes de Dados Jornal O Imparcial}

I CONFERÊNCIA DA CIDADE. A cidade que queremos: construindo a cidadania. Folheto de divulgação do evento realizado em maio de 2003, no Espaço Cultural para todos.

GRAVINA, Boaventura. Urbanismo e Plano Diretor. Jornal O Imparcial, 9 abr. 1961.

JORNAL O IMPARCIAL de Araraquara. Estamos às vésperas do planejamento do futuro do nosso município. O Imparcial, 22 jan. 1963.

Entrega do Plano Diretor de Araraquara. $O$

Imparcial, 27 dez. 1963, p. 7, 1963.

Boaventura. O Plano Diretor do Município de Araraquara. O Imparcial, sábado, 3 dez. 1977.

Boaventura. Plano Diretor do Município de Araraquara. O Imparcial, 20 nov. 1987, n. 14.317, p. 6-8, 1987.

Caderno especial: de Santi o prefeito do século.

Domingo, 22 ago. 1999.

SISTEMA MUNICIPAL de Planejamento Urbano e Ambiental (SMPUA). Processo de planejamento estratégico na concepção e formulação do PDPUA. Prefeitura Municipal de Araraquara, 2002.

\section{Documentos Arquivo Histórico (Intermediário) de Araraquara}

ATA DO CONSELHO CONSULTIVO MUNICIPAL em reunião realizada em 1932.

CÂMARA MUNICIPAL DE ARARAQUARA. Requerimento do Sr. Joaquim Vieira dos Santos, apresentado à Câmara Municipal em 1930.

CÂMARA MUNICIPAL DE ARARAQUARA. Requerimento do Sr. Joaquim Vieira dos Santos, apresentado à Câmara Municipal em 27 de julho de 1931.
CÂMARA MUNICIPAL DE ARARAQUARA. Ofício n. 209/51, envio de autógrafo de lei aprovada dispondo sobre a criação do Plano Urbanístico da cidade.

CÂMARA MUNICIPAL DE ARARAQUARA. Secretaria. Processo n. 124 de 4 de maio de 1937. Interessado: Joaquim Vieira dos Santos. Título: pedido de isenção. Assunto: requerimento 37/38 do interessado de isenção de taxa de água para a Granja da Villa Vieira de sua propriedade, situada neste município.

CONTRATO DE LOCAÇÃO DE SERVIÇOS profissionais n. 272 de 6 de agosto de 1969. CONTRATO DE LOCAÇÃO DE SERVIÇOS profissionais n. 273 de 6 de agosto de 1969.

CONTRATO DE LOCAÇÃO DE SERVIÇOS profissionais n. 277 de 19 de agosto de 1969.

CONTRATO DE LOCAÇÃO DE SERVIÇOS profissionais n. 278 de 20 de agosto de 1969.

DIRETORIA DE OBRAS E SERVIÇOS PÚBLICOS DE ARARAQUARA. Solicitação de produção de levantamento aerofotogramétrico do Cadastro Geral de Araraquara, 17 de outubro de 1952.

DIRETORIA DE EXPEDIENTE DA PREFEITURA Municipal de Araraquara. Parecer datado de $1^{\circ}$ de junho de 1951 instruindo veto à lei que aprovava a criação do Plano Urbanístico da cidade de Araraquara.

LEI n. 1.697 de 2 de junho de 1969. Dispõe sobre a criação do Departamento Autônomo de Água e Esgotos de Araraquara (DAAE).

LIVRO DE REGISTRO de Portarias da Prefeitura Municipal de Araraquara. Período de 13/2/1936 a 31/12/1938

OFÍCIO do Grupo de Trabalho do Plano Diretor de Araraquara, 1967, p. 7. Relatório a respeito dos estudos e levantamentos elaborados até o ano de 1967.

OFÍCIO do Grupo de Trabalho do Plano Diretor de Araraquara, 1972, p. 7. Relatório enviado ao prefeito Rubens Cruz em que se apresentam as conclusões a respeito dos levantamentos produzidos até a data.

PREFEITURA MUNICIPAL DE ARARAQUARA, Ofício n. 0079/2005, de 24 de janeiro de 2005, p. 3.

PREFEITURA MUNICIPAL DE ARARAQUARA. Diretoria do Expediente e Pessoal. Processo n. 1137/56 de 20 de agosto de 1956. Edital número 173 de concorrência pública para produção de levantamento aerofotogramétrico.

PREFEITURA MUNICIPAL DE ARARAQUARA. Diretoria de Obras e Serviços Públicos. Processo n. 21/52 de 17 de outubro de 1952. Cadastro: levantamento aerofotogramétrico do cadastro geral realizado pelo Aero Club de Araraquara.

PREFEITURA MUNICIPAL DE ARARAQUARA. Diretoria de Expediente e Pessoal. Processo n. 118/51 de 25 de setembro de 1951. Lei do Plano Urbanístico remetida ao Executivo municipal pelo Ofício n. 209/51. (Observação: esta lei foi vetada no todo pelo Executivo). PROCESSO n. 482-58, de 21 de fevereiro de 1958. 
Espólio de Boaventura Gravina. Arquivo Histórico (Intermediário) de Araraquara.

\section{Leis, Portarias e Atos - Arquivo Histórico (intermediário) de Araraquara}

ATO n. 54/61 de 17 de abril de 1962. Indica o vereador José Wellington Pinto para integrar a comissão do Plano Diretor de Araraquara.

ATO n. 4/69, de 7 de fevereiro de 1969. Indica o vereador Jobal Amaral Velosa para integrar a comissão do Plano Direto de Araraquara.

AUTÓGRAFO n. 205/61 de 5 de dezembro de 1961. Câmara Municipal de Araraquara constitui comissão do Plano Diretor.

AUTÓGRAFO n. 44/67, de 6 de novembro de 1967. Aprova normas urbanísticas para o município de Araraquara.

AUTÓGRAFO n. 41/68. Projeto de Lei n. 50/68, de 8 de outubro de 1968. Dispõe sobre a construção de conjuntos residenciais de Araraquara.

AUTÓGRAFO n. 40/68. Projeto de Lei n. 49/68, de 8 de outubro de 1968. Dispõe sobre recuo do alinhamento de edifícios de Araraquara.

AUTÓGRAFO n. 39/68. Projeto de Lei n. 48/68, de 22 de abril de 1968. Suspende a vigência do artigo 64 e seus parágrafos, da Lei n. 1632, de 22 de abril de 1968 , Araraquara.

AUTÓGRAFO n. 42/68. Projeto de Lei n. 51/68, s.d. Dispõe sobre recuo para edificações residenciais e comerciais de Araraquara.

AUTÓGRAFO n. 58/67. Projeto de Lei n. 79/67. Aprova em Sessão extraordinária de 11 de dezembro de 1967 a suspensão da vigência da Lei n. 1607, de 17 de novembro de 1967, que dispunha sobre as normas urbanísticas de Araraquara.

AUTÓGRAFO n. 6/68. Projeto de Lei n. 10/68, de 26 de março de 1968. Revoga a Lei n. 1607, de 17 de novembro de 1967 e aprova as normas urbanísticas para Araraquara. BRASIL. Lei n. 4.380 de 21 de agosto de 1964. Institui a Correção Monetária nos Contratos Imobiliários de Interesse Social, o Sistema Financeiro Para a Aquisição da Casa Própria, Cria o Banco Nacional de Habitação (BNH), e Sociedades de Crédito Imobiliário, as Letras Imobiliárias, o Serviço Federal de Habitação e Urbanismo e dá outras providências. Brasília: Presidência da República, 1964.

$$
\text { Lei n. } 10.257 \text { de } 10 \text { de julho de } 2001 .
$$

Regulamenta os artigos 182 e 183 da Constituição Federal, estabelece diretrizes gerais da política urbana e dá outras providências. Brasília: Congresso Nacional, 2001.

Lei n. 7.688, de 30 dezembro de 1971. Dispõe sobre a instituição do Plano Diretor de Desenvolvimento Integrado do Município de São Paulo (PDDI-SP) e dá outras providências. São Paulo: PMSP, 1971.

Lei n. 7.805 de $1^{\circ}$ de novembro de 1972.

Dispõe sobre o parcelamento, uso e ocupação do solo do município e dá outras providências. São Paulo: Prefeitura do Município de São Paulo, 1972.

Projeto de Lei do Plano Diretor do Município de São Paulo. DOMSP, 16 de março, v. 36, n. 50, 1991. (Suplemento).

Lei n. 13.430 de 13 de setembro de 2002. Institui o Plano Diretor Estratégico e o Sistema de Planejamento e Gestão do Desenvolvimento Urbano do Município de São Paulo. São Paulo: Prefeitura do Município de São Paulo, 2002.

. Lei n. 13.885, de 25 de agosto de 2004. Estabelece normas complementares ao Plano Diretor Estratégico, institui os Planos Regionais Estratégicos das Subprefeituras, dispõe sobre o parcelamento, disciplina e ordena o Uso e Ocupação do Solo do Município de São Paulo. São Paulo: PMSP, 2004.

LEI COMPLEMENTAR n. 434, de $1^{\circ}$ de dezembro de 1999. Dispõe sobre o desenvolvimento urbano no Município de Porto Alegre, institui o Plano Diretor de Desenvolvimento Urbano Ambiental de Porto Alegre e dá outras providências. Disponível em: <http://www. portoalegre.rs.gov.br/planeja/spm/default.htm>. Acesso em: 12 abr. 2011.

LEI Orgânica dos Municípios (Lei n. 9.842/67, posteriormente alterada pelo Decreto Lei Complementar n. 9 de 31 de dezembro de 1969).

LEI n. 1077 de 9 de dezembro de 1961. Constitui a Comissão do Plano Diretor de Araraquara.

LEI n. 1632, de 22 de abril de 1968. Revoga a Lei n. 1607 de 17 de novembro de 1967 e aprova as normas urbanísticas para Araraquara.

LEI n. 1662, de 15 de outubro de 1968. Dispõe sobre a construção de conjuntos residenciais de Araraquara.

LEI n. 1607, de 17 de novembro de 1967. Aprova normas urbanísticas para o município de Araraquara.

LEI n. 168 de 14 de janeiro de 1969. Dispõe sobre o cadastramento de terrenos de Araraquara.

LEI n. 1661, de 15 de outubro de 1968. Dispõe sobre o recuo do alinhamento de edifícios residenciais na zona comercial de Araraquara.

LEI n. 1620, de 27 de dezembro de 1967. Suspende a vigência da Lei n. 1607, de 17 de novembro de 1967, que dispunha sobre as normas urbanísticas.

LEI n. 5831, de 5 de junho de 2002. Institui o CMPUA de Araraquara.

PORTARIA n. 870 de 28 de fevereiro de 1955. Nomeia comissão do Plano Diretor.

PORTARIA n. 873 de 04 de março de 1955. Nomeia o professor Francisco Amendola da Silva, diretor da Escola de Belas Artes, como membro da comissão do Plano Diretor.

PORTARIA n. 1382 de 9 de dezembro de 1962. Nomeia comissão do Plano Diretor de Araraquara.

PORTARIA n. 1456, de 19 de outubro de 1962. Nomeia José Sérgio Andrade para integrar a comissão do Plano Diretor de Araraquara. 
PORTARIA n. 1650, de 30 de abril de 1964. Nomeia o engenheiro José dos Santos para integrar a comissão do Plano Diretor de Araraquara.

PORTARIA n. 1789, de 8 de março de 1969. Nomeia a comissão do Plano Diretor.

PORTARIA n. 1832, de 3 de junho de 1969. Concede demissão dos senhores Antonio Lupinacci Ramalho e Jobal Amaral Velosa da comissão do Plano Diretor de Araraquara.

PROJETO DE LEI n. 31/65, s.d. Desincorpora bem de uso comum do povo e dispõe sobre a construção por incorporação de edifício em condomínio de Araraquara. REQUERIMENTO n. 220/65 de 26 de abril de 1965. Solicita aprovação do projeto de construção de edifício onde se localizava o Teatro Municipal. Requerimento assinado pelo vereador Leonardo Crocci Filho de Araraquara.

SÃO PAULO [Estado]. Decreto n. 244, de 02 de março de 1894. Estabelece o Código Sanitário do Estado de São Paulo. Disponível em: <http://www.al.sp.gov.br/repositorio/ legislacao/decreto/1894/decreto-233-02.03.1894.html>. Acesso em: maio 2015.

\section{Entrevistas}

AZZONI, Alcyr. Depoimento [12 out. 2011]. Entrevistador: Rodrigo A. Toledo. Araraquara-SP, 2011. 1 cassete sonoro. Entrevista ao ex-presidente do COMPUA concedida à pesquisa de doutorado Trajetórias do Planejamento Urbano no Município de Araraquara: do Centralismo Decisório ao Plano Diretor Participativo.

GRAVINA, Vanda. Depoimento [out. 2011]. Entrevistador: Rodrigo A. Toledo. São Paulo, residência da entrevistada, 2011. 1 arquivo digital VOICE003.MP3. Entrevista concedida à pesquisa de doutorado Trajetórias do Planejamento Urbano no Município de Araraquara: do Centralismo Decisório ao Plano Diretor Participativo.

NEVES DA ROCHA FILHO, Gustavo. Depoimento [9 ago. 2011]. Entrevistador: Rodrigo Alberto Toledo. São Paulo-SP, 2011. 1 arquivo digital VOICE002.MP3. Entrevista concedida à pesquisa de doutorado Trajetórias do Planejamento Urbano no Município de Araraquara: do Centralismo Decisório ao Plano Diretor Participativo.

\title{
Trajectories of the urban planning: the managing plan of the decade of 1950 and the urban rearranging or reorganization of Araraquara, São Paulo, Brazil
}

\begin{abstract}
This article, an excerpt of the doctorate thesis Trajectories of the urban planning in Araraquara: from the power to decisive centralism to the participative managing plan, intends to dimension the forged urban chain in the State of São Paulo, Brazil. Based on Anhaia Mello' theses - university professor of the College of Architecture and Urbanism of the University of São Paulo (FAU-USP) -, it crystallized in the first elaborated managing plan in the city of Araraquara from 1950 on. This process of French and Anglo-American shades, in Araraquara, changed the knowledge on urban planning, producing an intended effect in the region. During the collection of the primary sources, it was clear that the proposals of FAU-USP incorporated in the urbanization norms of Araraquara, dictating the routes of the development of the urban public politics of the city in the middles of the decade of 1960.
\end{abstract}

Key words: urban planning, urban development, public politics and democracy.

\section{Trayectorias de la planificación urbana: el plan maestro de la década de 1950 y la remodelación urbana de Araraquara-SP}

\section{Resumen}

Este artículo pretende dimensionar cómo la corriente urbanística formada en el Estado de São Paulo - principalmente desde las tesis de Anhaia Mello, catedrático de la Facultad de Arquitectura y Urbanismo de la Universidad de São Paulo - FAU-USP - se cristalizó en el primer plan maestro elaborado en la ciudad de Araraquara desde 1950. Buscamos estructurar cómo ocurrió este proceso de cristalización de la corriente urbanística de São Paulo, con matices franceses y angloestadounidenses, en la ciudad de Araraquara, es 
decir, cuáles fueron los interlocutores clave, además del propio Anhaia Mello, para que esta transferencia de conocimientos de planificación urbana se hiciera efectiva en el municipio. Después de estudiar las fuentes primarias de investigación doctoral, Trayectorias de la planificación urbana en Araraquara: del centralismo de toma de decisiones al plan maestro participativo, en el Archivo Histórico Intermediario de Araraquara, en la Biblioteca de la FAU-USP, colecciones Anhaia Mello y el Centro de Pesquisa y Estudios Urbanísticos, el CEPEU, identificamos que las propuestas urbanísticas desarrolladas en la FAU-USP fueron difundidas e incorporadas en las normas urbanísticas de Araraquara, dictando la dirección del proceso de formulación de políticas públicas urbanas en la ciudad, desde mediados de la década de 1960.

Palabras clave: planificación urbana, plan maestro, desarrollo urbano, políticas públicas, democracia.

Data de recebimento do artigo: 25/2/2014

Data de aprovação do artigo: 18/11/2014 